\title{
Geological factors controlling occurrence and distribution of arsenic in groundwaters from the southern margin of the Duero Basin, Spain
}

\author{
Elena Giménez-Forcada \\ Instituto Geológico y Minero de España - IGME, Unidad de Salamanca. Calle Azafranal 48, 37001 Salamanca, Spain \\ e.gimenez@igme.es \\ Pauline L Smedley \\ British Geological Survey - BGS, Keyworth, Nottingham NG12 5GG, UK \\ pls@bgs.ac.uk
}

\begin{abstract}
Groundwater from springs and boreholes on the southern edge of the Cenozoic Duero Basin (DB) of Spain has concentrations of arsenic (As) which are commonly above the EC drinking-water limit of $10 \mu \mathrm{g} / \mathrm{L}$, and reach observed values up to $241 \mu \mathrm{g} / \mathrm{L}$. Groundwater compositions within the sedimentary aquifer vary from $\mathrm{Ca}-\mathrm{HCO}_{3}$ type, variably affected by evaporation and agricultural pollution at shallow levels, to $\mathrm{Na}$ $\mathrm{HCO}_{3}$ compositions in deeper boreholes of the basin. Groundwater conditions are mainly oxidising but reducing groundwaters exist in sub-basins within the aquifer, localised flow paths likely being influenced by basement structure. Arsenic concentrations are spatially variable, reaching up to $38 \mu \mathrm{g} / \mathrm{L}$ in springs of the Spanish Central System (SCS) basement aquifer and up to $62 \mu \mathrm{g} / \mathrm{L}$ in springs from the DB. Highest As concentrations are associated with the $\mathrm{Na}-\mathrm{HCO}_{3}$ compositions in deep boreholes (200-450 $\mathrm{m}$ depth) within the DB. These have high $\mathrm{pH}$ values (up to 9.6) can give rise to associated elevated concentrations of $V$ and $U$ (up to $64 \mu \mathrm{g} / \mathrm{L}$ and $30 \mu \mathrm{g} / \mathrm{L}$ respectively). In the deep borehole waters of the $D B$, oxidising flows derived from the mineralised igneous-metamorphic basement and discharging via major faults, are considered the origin of the higher concentrations. Compositions are consistent with desorption of As and other anionic species from metal oxyhydroxides in an oxic environment. Under locally reducing conditions prevalent in some low-flow parts of the $\mathrm{DB}$, an absence of detectable dissolved As is coincident with low or undetectable $\mathrm{SO}_{4}$ concentrations, and consistent with loss via formation of authigenic sulphide minerals. Mitigation measures are needed urgently in this semi-arid region where provision of alternative sources of safe drinking water is logistically difficult and expensive.
\end{abstract}

KEY WORDS: Arsenic, semi-arid region, water quality, hydrogeochemistry, water policy, environmental health. 
Giménez-Forcada, E.; Smedley, P.L. (2014). Geological factors controlling occurrence and distribution of arsenic in groundwaters from the southern margin of the Duero Basin, Spain. Environ Geochem Health. 36(6):1029-47.

DOI: 10.1007/s10653-014-9599-2

\section{Introduction}

A number of European countries, including France, Greece, Hungary, Italy, Portugal, Romania and Spain, have groundwater with concentrations of As above the EC drinking-water limit of $10 \mu \mathrm{g} / \mathrm{L}$. In Spain, problems related to the presence of As have increased significantly in recent years. This results from the change in EC regulations and corresponding change in the Royal Decree, RD 140/2003 (BOE 45, 2003), both of which reduced the limit from $50 \mu \mathrm{g} / \mathrm{L}$ to $10 \mu \mathrm{g} / \mathrm{L}$ in line with WHO recommendations (WHO, 2011). One of the worst-affected areas of Spain is located in the Cenozoic aquifers of the Duero Basin (DB), where As contamination was first detected during routine drinking-water surveillance (Fernández et al., 2004).

Groundwater is a vital resource in the semi-arid areas of the basin and is relied upon heavily for potable supply and agricultural production. In some areas of the basin, As concentrations in groundwater reach values up to several hundreds of $\mu \mathrm{g} / \mathrm{L}$ (maximum observation $640 \mu \mathrm{g} / \mathrm{L}$ from a study by Sahún et al., 2004). This situation affects the groundwater used for drinking purposes in several townships of Segovia and Valladolid. On the southern edge of the basin, concentrations are generally lower, sometimes only slightly above the limit, but sufficient to invalidate its use for drinking water. The situation has been managed by the distribution of bottled water to the local population and more recently with the installation of water treatment plants which abstract water from nearby reservoirs. These inevitably lead to an increase in costs for users. The rising demands for drinking water often cannot be met by surface-water supplies alone.

The impact on health of As exposure from drinking water has not been defined for the region. No increased incidences of bladder or lung cancer have been noted in the districts of the DB (Lopez-Abente et al., 2006; Aragonés et al., 2009). However, Aragonés et al. (2009) found a clear geographic pattern of gastric cancer incidence in Spain, with highest incidence coinciding with the DB. While gastric cancer has not been clearly linked to As exposure, environmental exposure via drinking water was highlighted as one possible cause of the distributions observed.

The study area is located close to the central-southern edge of the Cenozoic Duero Basin (Figure 1a), where a major lithological contrast exists between the sedimentary basin and the igneous and metasedimentary basement of the Spanish Central System (SCS). The Spanish-Portuguese Duero river basin is located in the northwestern part of the Iberian Peninsula and contains the largest of the peninsular rivers (572 km in Spanish territory). The basin has an area of $97,290 \mathrm{~km}^{2}$ and groundwater is used mainly for public supply and irrigated agriculture.

The source of As in DB groundwater is established as natural (Barroso et al., 2002, García-Sánchez \& Álvarez-Ayuso, 2003; Fernández et al., 2004; Sahún et al., 2003, 2004; García-Sánchez et al., 2005; Gómez et al., 2006; Pardo et al., 2008; Moyano et al., 2008; Delgado et al., 2009). Delgado et al. (2009) found arsenic contents of 10-50 $\mathrm{mg} / \mathrm{kg}$ in the Neogene sediments of the basin. Sahún et al. $(2003,2004)$ and Gómez et 
Giménez-Forcada, E.; Smedley, P.L. (2014). Geological factors controlling occurrence and distribution of arsenic in groundwaters from the southern margin of the Duero Basin, Spain. Environ Geochem Health. 36(6):1029-47.

DOI: 10.1007/s10653-014-9599-2

al. (2006) related the high concentrations of As in groundwater to the sediments of the Zaratán Facies (Middle Miocene) and proposed mobilisation of arsenic by desorption from Fe and Mn oxyhydroxides, under oxidising and alkaline conditions. García-Sánchez et al. (2005) linked the release to competition between $\mathrm{HCO}_{3}$ and arsenate for sorption sites on oxyhydroxides under oxic conditions. Although these numerous studies have provided insights into the nature and distribution of the As problem in the region, the causes of the problem are not fully resolved.

The main objective of this paper is to identify the key geological factors controlling arsenic incorporation, mobility and distribution in the aquifers and to establish their impacts on water supply.

\section{Geological and hydrogeological background}

The study area is located where the northern edge of the Spanish Central System overthrusts the sediments of the Duero Basin (Figure 1b). The SCS is an intraplate Cenozoic thick-skin pop-up with an E-W to NE-SW main trend. This forms the most prominent topography in the interior of the Iberian Peninsula (Gómez Ortíz and Babín Vich, 1996; De Vicente et al., 2007). The northern edge of this structural unit is bounded by the Cenozoic DB which occupies a large area of the Iberian Peninsula. Sediment infill is continental and controlled by the tectonic activity of the margins. The basement is formed by Neoproterozoic to Mesozoic SCS rocks. Tectonic features comprise a pervasive fault network and the DB southern margin is generally tectonic. The MessejanaPlasencia basic dyke (MPD), a SW-NE slightly-curved alignment stretching more than $500 \mathrm{~km}$, forms one of the principal structures of the Iberian Peninsula. The northern extreme of the dyke disappears under the Neogene cover of DB (Palencia et al., 2006). It can be assumed that the clear gravimetric and magnetic lineaments in the DB reflect unveiled basement structures that must also affect the sedimentary cover. This interpretation is supported by the tectonic control of numerous stratigraphic units (Alonso-Gavilán et al., 2004).

Metalliferous minerals on the north rim of the SCS include rare occurrences of lead, copper and uranium ore (Junta de Castilla y León and IGME databases) as well as ores of $W$, $\mathrm{Sn}, \mathrm{As}, \mathrm{Au}, \mathrm{Zn}$ and $\mathrm{Ag}$, along with fluorite and barite. Skarns include $\mathrm{W}, \mathrm{Cu}, \mathrm{Zn}, \mathrm{Sn}$ and $\mathrm{Fe}$; episyenites contain veins of $\mathrm{W}, \mathrm{Cu}, \mathrm{Zn}$ and $\mathrm{Sn}$, and greisens contain $\mathrm{W}$ and $\mathrm{Cu}$ (Jiménez Benayas et al., 1997). Secondary arsenic minerals, including scorodite, have also been recorded in some areas of SCS (e.g. Barrios Sánchez et al., 2008; Murciego et al., 2009).

The $D B$ is the most important aquifer of the region. The aquifer is mainly unconfined, though confined sections may be identified locally at depth, associated with overlying discontinuous clay horizons. The main recharge to the DB aquifer is via meteoric infiltration of $2.28 \times 10^{8} \mathrm{~m}^{3} /$ year (Sahún 2004) and, in natural conditions, the main discharge is the Duero river, which is the most important drainage channel of the 
Giménez-Forcada, E.; Smedley, P.L. (2014). Geological factors controlling occurrence and distribution of arsenic in groundwaters from the southern margin of the Duero Basin, Spain. Environ Geochem Health. 36(6):1029-47.

DOI: 10.1007/s10653-014-9599-2

basin. Abstraction is from boreholes with depths ranging from $50 \mathrm{~m}$ to $450 \mathrm{~m}$ (the most common depth range is 160-200 $\mathrm{m}$ ). In recent decades, with the continued abstraction of groundwater, the water level has been declining. The rivers Zapardiel and Trabancos are ephemeral, flowing only due to surface runoff (Sánchez, 2006).
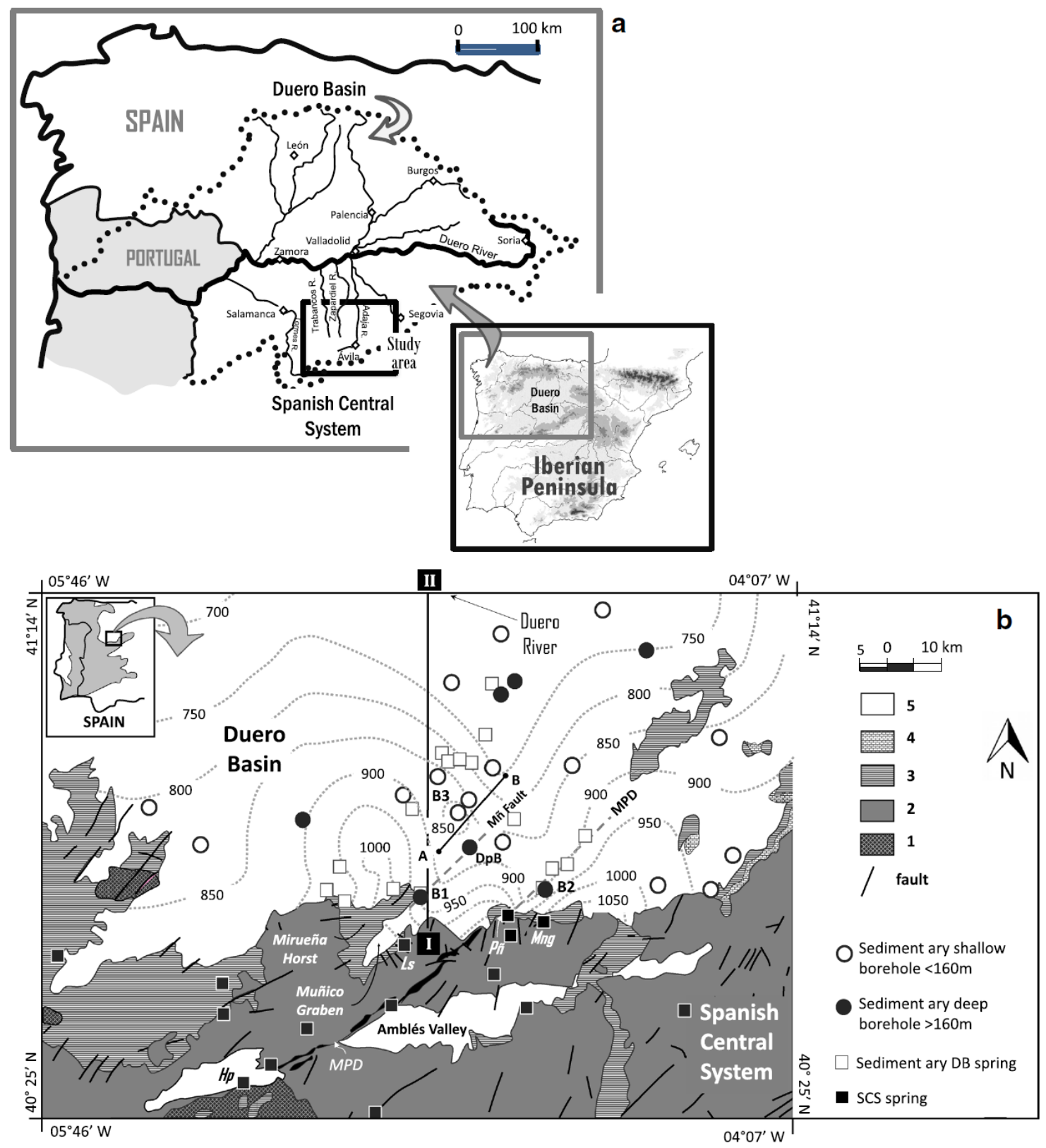

Figure 1. (a) Location of the Duero Basin and study area; (b) simplified map with the main geological and hydrogeological features, including piezometric surface. Geology: 1. Migmatite; 2. Granite; 3. Metasedimentary rocks; 4. Cretaceous carbonate; 5. Cenozoic and Quaternary sediments. MPD: Messejana-Plasencia dyke. rw: recharge water end member; hp: 'huevos podridos' spring; Is: 'la salud' spring. I-II Geological and hydrogeological cross-section, given in Figure $2 \mathrm{a}$. 
Giménez-Forcada, E.; Smedley, P.L. (2014). Geological factors controlling occurrence and distribution of arsenic in groundwaters from the southern margin of the Duero Basin, Spain. Environ Geochem Health. 36(6):1029-47.

DOI: 10.1007/s10653-014-9599-2

The local climate is Mediterranean, although markedly continental. Temperatures average $10.5-12^{\circ} \mathrm{C}$ and annual rainfall is $600 \mathrm{~mm}$. The lowest values ( $\leq 400 \mathrm{~mm}$ ) are recorded in the south of the basin, in the rain shadow of the SCS. Winters are cold (average temperature in the winter months $<5^{\circ} \mathrm{C}$ ) and summers short and arid.

The general flow of groundwater in the study area is S-N, towards the Duero River (Figure 2a), although some anomalies can be identified in relation to basement structure and the probable creation of small isolated sub-basins or even perched aquifers. The groundwater piezometric surface (Figure 1b), particularly the 900 m.a.s.l. contour, shows a significant deflection near the prolongation of the major Muñico Fault (Mñ Fault) and Messejana-Plasencia dyke (MPD) systems. The groundwater contours reveal two important flow paths, linked to these fault structures originating in the SCS and extending into the sedimentary aquifer of the DB. The delineation of the subsurface faults is noted also by the location of the main spring waters in the study area. Further, an irregularity in water head is noted (850 m.a.s.I.; Figure 2b), probably again relating to the influence of the basement structure. Closely-spaced points have more than $100 \mathrm{~m}$ difference in piezometric level, which could be interpreted as a small perched aquifer associated with a horst structure.

\section{Methods}

In order to check for relationships between waters draining fissured aquifers of the SCS and sedimentary aquifers of the DB, water samples were taken in both environments from the study area: springs were sampled in SCS and both springs and boreholes in DB. Spring water samples $(n=32)$ were collected during December 2010 and April 2011. Groundwaters from three boreholes in the DB aquifer (B1, B2, and B3) were sampled in November 2012. In each case, sampling took place during the rainy season.

Flowing spring samples were collected in a receptacle and field measurements taken rapidly to capture representative in-situ compositions. Samples from boreholes were taken from installed pumps or directly when artesian. Site locations were determined by Garmin GPS with UTM, which is accurate to around $5 \mathrm{~m}$. On-site analysis included water temperature, $\mathrm{pH}, \mathrm{ORP}$ (oxidation-reduction potential) and EC (electrical conductance, $25^{\circ} \mathrm{C}$ ). For the first and third sampling period, a Hanna portable $\mathrm{pH}$ instrument ( $\mathrm{HI}$ 9025C) was used, while a Thermo Scientific Orion 250A pH/Electrode was used for the second. The ORP electrode response was checked daily against fresh Zobell's solution. In all cases, field-measured ORP readings were corrected for the standard hydrogen electrode and Eh values are reported.

At each site, water samples were also collected for laboratory analysis. Samples for major and trace-element analysis were filtered $(0.45 \mu \mathrm{m})$ on site into factory-new polyethylene bottles. Those collected for analysis of cations were acidified to $1 \% \mathrm{v} / \mathrm{v}$ with Suprapur ${ }^{\circledR} \mathrm{HNO}_{3}(65 \%)$ and analysed as soon as possible following collection. Unacidified groundwater samples collected for arsenic speciation were refrigerated at 
Giménez-Forcada, E.; Smedley, P.L. (2014). Geological factors controlling occurrence and distribution of arsenic in groundwaters from the southern margin of the Duero Basin, Spain. Environ Geochem Health. 36(6):1029-47.

DOI: 10.1007/s10653-014-9599-2

$4^{\circ} \mathrm{C}$ and analyzed within one week of collection at the laboratories of the University of Valladolid. Chemical analyses from the first and third sampling campaign were carried out in the Instituto Geológico y Minero de España (IGME) laboratories and the second batch of samples was analysed in the British Geological Survey (BGS) laboratories. In the IGME laboratory, $\mathrm{Ca}$ and $\mathrm{Mg}$ were measured by AAS-CFA (Atomic Absorption Spectrophotometry-Continuous Flow Analysis), $K$ and $B$ were measured by ICP-AES, As and $\mathrm{Sr}$ by ICP-MS and lithium by AAS. Fluoride was determined by ion-selective electrode. In the BGS laboratories, major cations, $\mathrm{SO}_{4}$ and trace elements including As were analysed by ICP-MS (Agilent 7500cx fitted with an Octopole Reaction System collision-cell interface). Chloride, $\mathrm{NO}_{3}$ and $\mathrm{F}$ were determined by ion chromatography. Electrical charge imbalances were in all cases less than $3 \%$.

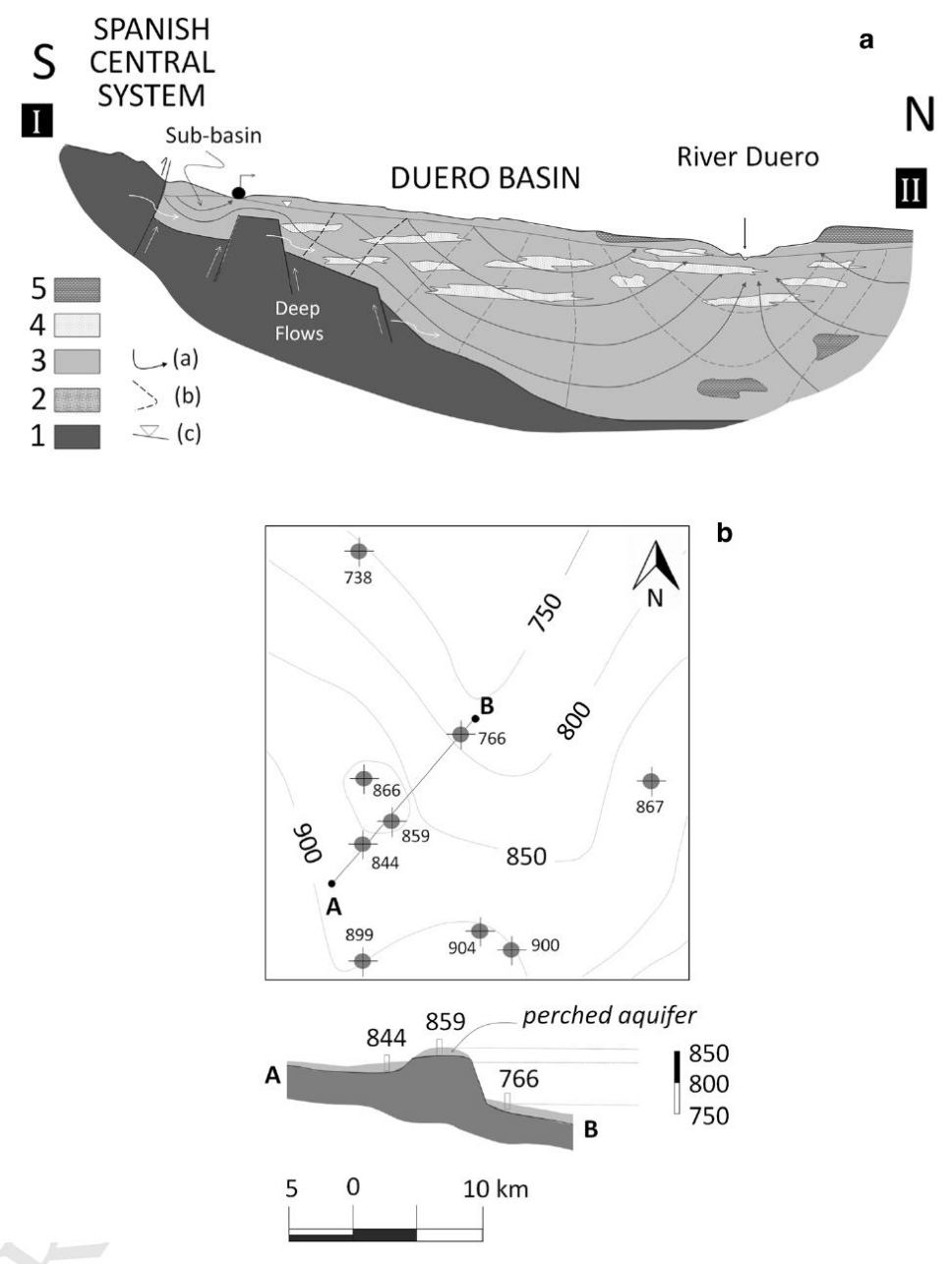

Figure 2. (a) Schematic geological and hydrogeological cross section of the contact zone between the Spanish Central System (SCS) (basement) and the southern edge of the Duero Basin (DB), and interpretation of groundwater flow (IGME, 2008; Sánchez, pers. commun., 2013). Presence of small sub-basins controlling local flow is also indicated. Legend: (1) impermeable basement; (2) gravel and conglomerate in arkosic sludge matrix; (3) Cenozoic sediment; (4) pans of sand and gravel; (5) clay and silt. a) flow line; b) equipotential line; c) piezometric surface. (b) Schematic interpretation of the anomaly outlining the piezometric isoline 850 m.a.s.l., detected against Mirueña Horst. 
Giménez-Forcada, E.; Smedley, P.L. (2014). Geological factors controlling occurrence and distribution of arsenic in groundwaters from the southern margin of the Duero Basin, Spain. Environ Geochem Health. 36(6):1029-47.

DOI: 10.1007/s10653-014-9599-2

Arsenic speciation was carried out on a small number of samples by HPLC-ICP-MS. Arsenite and arsenate ions were separated on an Agilent G3154A HPLC column before detection by an Agilent 7500 Series ICP-MS (Day et al., 2002; Milstein et al., 2002; Li et al., 2010; Komorowicz and Barałkiewicz, 2011). Concentrations of arsenic species in the water samples were quantified by interpolation in the respective linear calibration plots, obtained for concentrations $0.5-100 \mu \mathrm{g} / \mathrm{L}$. Sample dilution was required in some cases.

In addition to the collected groundwater samples, 20 analyses of good quality (full analysis and analytical charge imbalances $<5 \%$ ) were selected for the defined study area from the water-quality network of the Duero River Basin District ('Confederación Hidrográfica del Duero', MAGRAMA). The data, considered representative of borehole water in the study area, derive from samples collected in 2008 (autumn and summer), 2009 (autumn), and 2010 (summer and winter).

\section{$4 \quad$ Results}

The chemical compositions of the groundwaters are mainly $\mathrm{Ca}-\mathrm{HCO}_{3}$, mixed-cation$\mathrm{HCO}_{3}$ and $\mathrm{Na}-\mathrm{HCO}_{3}$ types. Table 1 shows the main hydrochemical facies in the different environments and Figure 3 shows the distributions in a Piper diagram. Representative chemical analyses for groundwaters are shown in Table 2, and summary statistical data are summarized in Table 3.

\subsection{SCS groundwater}

Fifteen spring water points sampled in the northern sector of the SCS near the contact with Cenozoic DB sediments, indicate a large range in $\mathrm{pH}$ from slightly acidic to strongly alkaline (range 5.85-9.98). Carbonate reactions in the carbonate-rich aquifers are likely important processes, with generation of high $\mathrm{pH}$ values and presence of $\mathrm{CO}_{3}$ in a minority of high-pH samples. The groundwaters are usually oxidising with redox potentials (Eh values) up to $473 \mathrm{mV}$. By contrast, two springs ('La Salud' (Ls) and 'Huevos podridos' ( $\mathrm{Hp}$ ) show much lower values (around 17 and $115 \mathrm{mV}$ respectively) and are characterized by a smell of sulphide, in correspondence with low concentrations of $\mathrm{SO}_{4}(<1 \mathrm{mg} / \mathrm{L})$. The range in concentrations of sulphate for the springs is large (up to $148 \mathrm{mg} / \mathrm{L}$, median $15 \mathrm{mg} / \mathrm{L}$ ).

TDS values are in the range 38-1270 $\mathrm{mg} / \mathrm{L}$, the highest values located near the contact with DB. The hydrochemical facies of the SCS springs are $\mathrm{Na}-\mathrm{HCO}_{3}(46.5 \%), \mathrm{Ca}-$ $\mathrm{HCO}_{3}(46.5 \%)$ and $\mathrm{Ca}-\mathrm{Cl}$ (7\%) (Table 1). Sodium (6-106 mg/L, median $15 \mathrm{mg} / \mathrm{L}$ ) is the most prevalent cation in the higher areas of the SCS. Under the oxic conditions, nitrate concentrations are high in some samples, with a variation between $<0.5 \mathrm{mg} / \mathrm{L}$ and 113 $\mathrm{mg} / \mathrm{L}\left(\mathrm{NO}_{3}\right)$, and a median of $17 \mathrm{mg} / \mathrm{L}$. Concentrations of $\mathrm{Fe}$ and $\mathrm{Mn}$ are correspondingly usually low (median values of 0.8 and $10 \mu \mathrm{g} / \mathrm{L}$ respectively). 
Giménez-Forcada, E.; Smedley, P.L. (2014). Geological factors controlling occurrence and distribution of arsenic in groundwaters from the southern margin of the Duero Basin, Spain. Environ Geochem Health. 36(6):1029-47.

DOI: $10.1007 / \mathrm{s} 10653-014-9599-2$

Table 1

Percentages of main hydrochemical facies.

\begin{tabular}{lcccc}
\hline Hydrochemical Facies & $\begin{array}{c}\text { Spring waters } \\
\text { In SCS }\end{array}$ & $\begin{array}{c}\text { Spring waters } \\
\text { In DB }\end{array}$ & $\begin{array}{c}\text { Shallow } \\
\text { Boreholes (DB) }\end{array}$ & $\begin{array}{c}\text { Deep } \\
\text { Boreholes (DB) }\end{array}$ \\
\hline Bicarbonate waters & $93 \%$ & $64 \%$ & $60 \%$ & $60 \%$ \\
Chloride waters & $7 \%$ & $0 \%$ & $27 \%$ & $40 \%$ \\
Other & $0 \%$ & $36 \%$ & $13 \%$ & $0 \%$ \\
Calcium waters & $53 \%$ & $100 \%$ & $54 \%$ & $0 \%$ \\
Sodium waters & $47 \%$ & $0 \%$ & $33 \%$ & $100 \%$ \\
Other & $0 \%$ & $0 \%$ & $13 \%$ & $0 \%$ \\
& & & & \\
Ca-HCO & & & & \\
Na- $\mathrm{HCO}_{3}$ facies & $46.5 \%$ & $64 \%$ & $46 \%$ & $0 \%$ \\
Na-Cl facies & $46.5 \%$ & $0 \%$ & $14 \%$ & $60 \%$ \\
Other & $0 \%$ & $0 \%$ & $27 \%$ & $40 \%$ \\
\hline
\end{tabular}

Table 2

Representative analyses of groundwaters from the study area.

\begin{tabular}{|c|c|c|c|c|c|c|c|c|c|c|c|c|c|c|c|}
\hline Sample & & 'La Salud' & $\begin{array}{l}\text { 'Huevos } \\
\text { Podridos' }\end{array}$ & $\begin{array}{l}\text { Peñalba } \\
\text { Pñ }\end{array}$ & $\begin{array}{l}\text { Mingorría } \\
\text { Mng }\end{array}$ & DB46 & DB47 & DB53 & DB56 & SB6 & S21 & DpB & B1 & B2 & B3 \\
\hline $\begin{array}{l}\text { Groundwater } \\
\text { type }\end{array}$ & & Spring SCS & S Spring SCS & SSpring SCS & SSpring SCS & Spring DB & B Spring DB & B Spring DB & B Spring DB & $\begin{array}{l}\text { Borehole } \\
\text { MAGRAMA }\end{array}$ & $\begin{array}{l}\text { Borehole } \\
\text { MAGRAMA }\end{array}$ & $\begin{array}{l}\text { Borehole } \\
\text { MAGRAMA }\end{array}$ & $\begin{array}{l}\text { Borehole } \\
\text { DB }\end{array}$ & $\begin{array}{l}\text { e Borehole } \\
\text { DB }\end{array}$ & $\begin{array}{l}\text { Borehole } \\
\text { DB }\end{array}$ \\
\hline Borehole depth & $\mathrm{m}$ & - & - & - & - & - & - & - & - & 35 & 70 & 450 & 220 & 270 & 160 \\
\hline Spring elevation & $\mathrm{m}$ & 1183 & 1021 & 1064 & 1025 & 922 & 985 & 846 & 1032 & - & - & - & - & - & - \\
\hline Latitude & ${ }^{\circ} \mathrm{N}$ & 40.71 & 40.48 & 40.77 & 40.75 & 40.84 & 40.80 & 41.04 & 40.80 & 40.92 & 41.20 & 40.87 & 40.80 & 40.80 & 40.98 \\
\hline Longitude & ${ }^{\circ} \mathrm{W}$ & 4.98 & 5.32 & 4.75 & 4.66 & 4.62 & 4.94 & 4.80 & 5.00 & 5.54 & 4.78 & 4.84 & 4.93 & 4.67 & 4.91 \\
\hline Sample date & & Dec-10 & Dec-10 & Apr-11 & Apr-11 & Apr-11 & Apr-11 & Apr-11 & Dec-10 & May-08 & Dec-10 & Jun-10 & Nov-12 & Nov-12 & Nov-12 \\
\hline Temperature & ${ }^{\circ} \mathrm{C}$ & 9.4 & 5.7 & 10.9 & 10.4 & 11.8 & 11.7 & 11.6 & 11.7 & 18.2 & 13.7 & 25.2 & 16 & 17 & 9.9 \\
\hline$S_{E C}{ }^{a}$ & $\mu \mathrm{S} \mathrm{cm}^{-1}$ & -1260 & 391 & 946 & 1660 & nd & nd & nd & 556 & 497 & 188 & 674 & 347 & 310 & 257 \\
\hline $\mathrm{pH}$ & units & 9.98 & 7.86 & 7.27 & 7.44 & 7.36 & 6.98 & 7.24 & 7.19 & 7.53 & 9.38 & 9.22 & 9.62 & 9.41 & 9.34 \\
\hline Eh & $\mathrm{mV}$ & 17 & 115 & 390 & 397 & 400 & 421 & 404.9 & 409 & nd & nd & nd & 428 & 401 & 27 \\
\hline $\mathrm{HCO}_{3}$ & $\mathrm{mg} \mathrm{l}^{-1}$ & 99 & 99 & 317 & 532 & 158 & 288 & 250 & 286 & 191 & 70 & 276 & 252 & 189 & 109 \\
\hline $\mathrm{CO}_{3}$ & $\mathrm{mg} \mathrm{|}^{-1}$ & nd & nd & nd & nd & $<1$ & $<1$ & $<1$ & $<1$ & nd & nd & nd & 4.83 & 6.04 & 8.5 \\
\hline $\mathrm{Cl}$ & $\mathrm{mg} \mathrm{l}^{-1}$ & 13.0 & 56.0 & 71.9 & 147 & 36.5 & 45.8 & 119.2 & 32.8 & 16.9 & 13.5 & 16.7 & 15 & 16 & 15 \\
\hline $\mathrm{SO}_{4}$ & $\mathrm{mg} \mathrm{l}^{-1}$ & 19.0 & 28.0 & 64.9 & 148 & 59.9 & 91.6 & 66.8 & 4.32 & 34.4 & $<1$ & 33.6 & 22 & 22 & 17 \\
\hline $\mathrm{NO}_{3}$ & $\mathrm{mg} \mathrm{l}^{-1}$ & $<0.5$ & $<0.5$ & 72.5 & 113 & 132 & 118 & 146.1 & 16.3 & 27.1 & $<0.5$ & 2.40 & 2 & 4 & 5 \\
\hline $\mathrm{Ca}$ & $\mathrm{mg} \mathrm{l}^{-1}$ & 1.0 & $<1$ & 120 & 130 & 68.2 & 135 & 132 & 57.3 & 45.6 & 2.80 & $<1$ & 1 & 1 & 1 \\
\hline $\mathrm{Mg}$ & $\mathrm{mg} \mathrm{l}^{-1}$ & 3.0 & 1.0 & 21.8 & 66.8 & 15.3 & 15.9 & 32.9 & 26.1 & 11.6 & 2.50 & 0.50 & 2 & 3 & 7 \\
\hline $\mathrm{Na}$ & $\mathrm{mg} \mathrm{l}^{-1}$ & 51.0 & 89.0 & 38.4 & 106 & 43.3 & 32.4 & 24.2 & 16.4 & 25.8 & 25.5 & 139 & 118 & 91 & 50 \\
\hline $\mathrm{K}$ & $\mathrm{mgl}^{-1}$ & $<1$ & 1.0 & 2.9 & 25.0 & 5.8 & 4.5 & 9.9 & 6.1 & 1.40 & 1.20 & 0.50 & $<1$ & 2 & $<1$ \\
\hline Facies & & $\mathrm{Na}-\mathrm{HCO}_{3}$ & $\mathrm{Na}-\mathrm{HCO}_{3}$ & $\mathrm{Ca}-\mathrm{HCO}_{3}$ & $\begin{array}{l}\mathrm{MixCa}- \\
\mathrm{MixHCO}_{3}\end{array}$ & $\begin{array}{l}\mathrm{Ca}- \\
\mathrm{MixHCO}_{3}\end{array}$ & $\begin{array}{l}\mathrm{Ca}- \\
\mathrm{Mix} \mathrm{HCO}_{3}\end{array}$ & $\begin{array}{l}\mathrm{Ca}- \\
\mathrm{MixHCO}_{3}\end{array}$ & $\begin{array}{l}\mathrm{MixCa}- \\
\mathrm{HCO}_{3}\end{array}$ & $\mathrm{Ca}-\mathrm{HCO}_{3}$ & $\mathrm{Na}-\mathrm{HCO} 3$ & $\mathrm{Na}-\mathrm{HCO}_{3}$ & $\mathrm{Na}-\mathrm{HCO} 3$ & $3 \mathrm{Na}-\mathrm{HCO} 3$ & $\mathrm{Na}-\mathrm{HCO} 3$ \\
\hline $\mathrm{F}$ & $\mathrm{mg} \mathrm{l}^{-1}$ & 6.9 & 14 & 0.32 & $<0.01$ & 0.15 & 0.49 & 0.366 & 0.36 & 2.55 & 0.21 & 2.26 & 2.0 & 3.0 & 0.6 \\
\hline $\mathrm{SiO}_{2}$ & $\mathrm{mg} \mathrm{l}^{-1}$ & 31.6 & 30.1 & 34.3 & 29.4 & 37.4 & 47.2 & 52.3 & 9.99 & nd & nd & nd & 15.3 & 15.3 & 0.5 \\
\hline $\mathrm{Sr}$ & $\mu \mathrm{gl}^{-1}$ & 17.9 & 19.7 & 792 & 1310 & 652 & 971 & 1693 & 270 & nd & nd & nd & nd & nd & nd \\
\hline $\mathrm{Mn}$ & $\mu \mathrm{gl}^{-1}$ & 0.92 & 5.0 & 0.90 & 0.40 & $<0.2$ & 0.40 & $<0.2$ & $<0.2$ & 10 & 4.00 & 1.0 & 0.71 & 0.57 & 6.46 \\
\hline $\mathrm{Fe}_{\mathrm{T}}$ & $\left.\mu g\right|^{-1}$ & 2.3 & nd & 8.0 & 3.0 & 2.0 & 3.0 & 1.0 & 2.0 & 10 & 170 & 10 & 20 & $<15$ & 42 \\
\hline $\mathrm{Li}$ & $\mu g \mathrm{I}^{-1}$ & 100 & 300 & 44 & 137 & 33 & 31 & 61 & 24.0 & nd & nd & nd & nd & nd & nd \\
\hline Mo & $\mu \mathrm{g} \mathrm{I^{-1 }}$ & nd & nd & nd & nd & nd & nd & nd & nd & nd & nd & nd & 1.71 & 1.01 & 64.9 \\
\hline B & $\left.\mu \mathrm{g} \mathrm{I}\right|^{-1}$ & 86 & 824 & $<10$ & 72.0 & $<10$ & $<10$ & $<10$ & $<10$ & nd & nd & nd & 190 & 113 & $<100$ \\
\hline v & $\mu \mathrm{gl}^{-1}$ & nd & nd & 7.10 & 19.8 & 6.70 & 18.7 & 13.9 & 0.20 & nd & nd & nd & 63.6 & 47.6 & 0.11 \\
\hline As & $\left.\mu g\right|^{-1}$ & 0.76 & 1.72 & 37.6 & 32.4 & 19.1 & 9.57 & 23.1 & 1.32 & 10.0 & 1.0 & 90 & 138 & 241 & 2.3 \\
\hline $\mathrm{Se}$ & $\left.\mu \mathrm{g}\right|^{-1}$ & nd & nd & 0.90 & 0.40 & 1.00 & 0.90 & 0.70 & 0.30 & nd & nd & nd & 1.1 & $<0.5$ & $<0.5$ \\
\hline $\mathrm{Y}$ & $\left.\mu g\right|^{-1}$ & nd & nd & 0.02 & 0.02 & 0.02 & 0.01 & 0.019 & 0.03 & nd & nd & nd & nd & nd & nd \\
\hline u & $\mu \mathrm{gl}^{-1}$ & nd & nd & 10.3 & 21.4 & 12.9 & 2.86 & 12.3 & 15.7 & nd & nd & nd & 30.3 & 11.7 & 0.05 \\
\hline $\mathrm{NH}_{4}$ & $\mathrm{mg} \mathrm{l}^{-1}$ & nd & nd & nd & nd & nd & nd & nd & nd & 0.32 & 1.95 & 0.05 & $<0.05$ & $<0.05$ & $<0.05$ \\
\hline TOC & $\mathrm{mg} \mathrm{l}^{-1}$ & nd & nd & nd & nd & nd & nd & nd & nd & 0.60 & 1.10 & 0.25 & 0.6 & 0.7 & 1.01 \\
\hline $\mathrm{SI}_{\text {calcite }}$ & units & 0.06 & - & 0.12 & 0.46 & -0.29 & -0.16 & 0.08 & -0.25 & -0.08 & 0.04 & -0.23 & 0.20 & 0.02 & 0.02 \\
\hline AsIIII & $\left.\mu g\right|^{-1}$ & - & - & - & - & - & - & - & - & - & - & - & 12.5 & 5.9 & 0.5 \\
\hline Asv & $\mu \mathrm{gl}^{-1}$ & - & - & - & - & - & - & - & - & - & - & - & 125.5 & 235.1 & 1.8 \\
\hline
\end{tabular}

a SEC: specific electrical conductance $\quad{ }^{b}$ nd: not determined

$\mathrm{SI}_{\text {calcite }}$ has been calculated using Phreeqc. 
Giménez-Forcada, E.; Smedley, P.L. (2014). Geological factors controlling occurrence and distribution of arsenic in groundwaters from the southern margin of the Duero Basin, Spain. Environ Geochem Health. 36(6):1029-47.

DOI: 10.1007/s10653-014-9599-2

Arsenic concentrations in the SCS springs vary over the range $0.1-37.6 \mu \mathrm{g} / \mathrm{L}$, with a median value of $1.02 \mu \mathrm{g} / \mathrm{L}$. The higher concentrations are present in oxidising waters; low concentrations characterise the reducing flows. Figure 4 shows the relationship between As, $\mathrm{pH}$ and concentrations of anions in the spring waters. In the SCS groundwaters, the large range in $\mathrm{pH}$ and alkalinity in particular is observed.

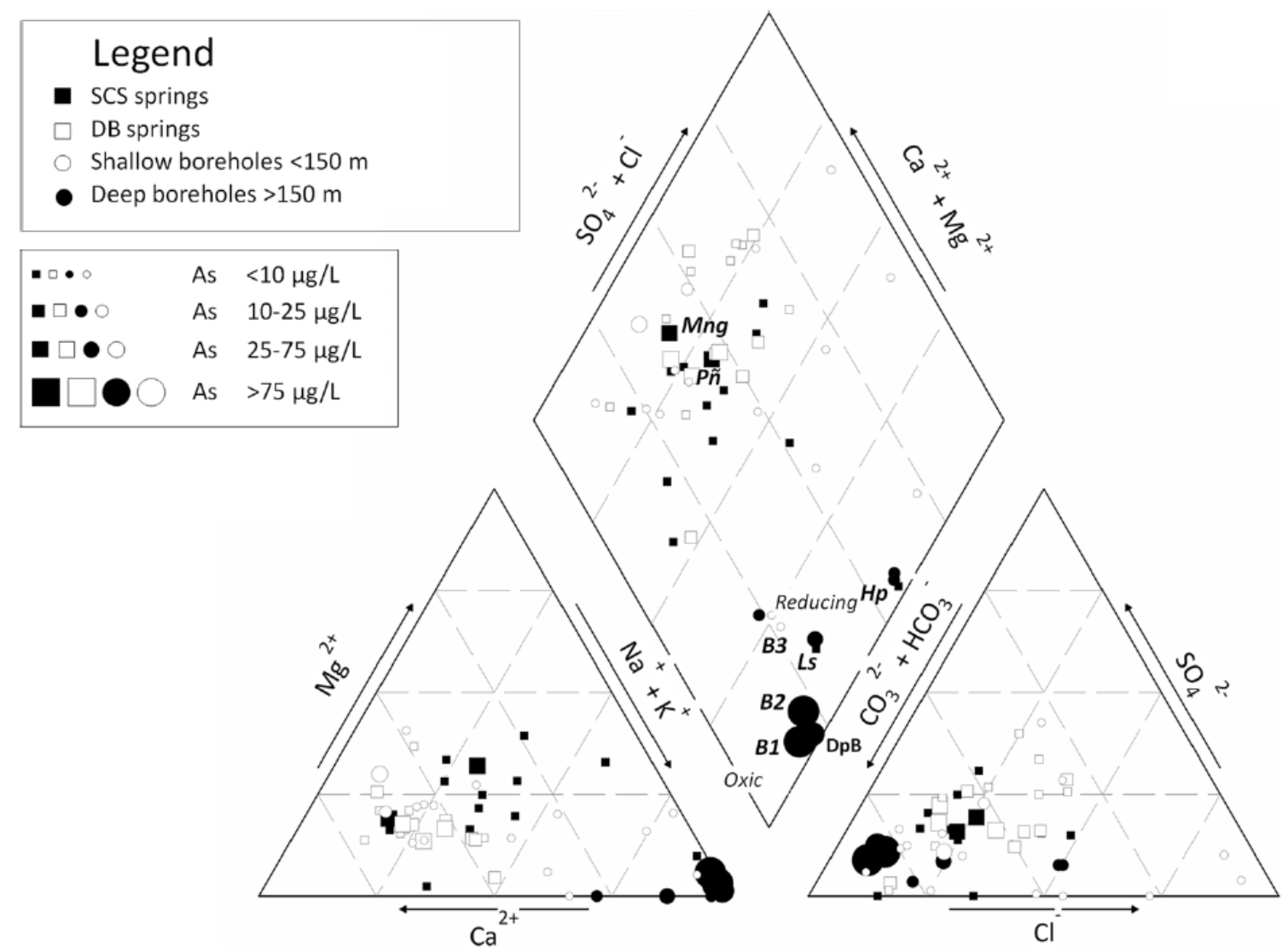

Figure 3. Piper diagram showing compositions of samples from springs and boreholes, together with As concentrations. Specific compositions of La Salud (Ls), Huevos podridos (Hp), Peñalba (Pñ) and Mingorría (Mng() springs and deep boreholes B1 and B2 are indicated. Symbol sizes denote As concentration ranges.

\subsection{DB groundwater}

DB spring water samples show a pH range of 6.15-7.99, which typically increases downgradient from the marginal areas to the basin plain. Saturation states with respect to calcite vary between -2.61 and 0.44 . The springwaters are usually oxidising with high redox potentials (Eh values up to $484 \mathrm{mV}$ ). Concentrations of Fe and $\mathrm{Mn}$ are also low $(<1-10 \mu \mathrm{g} / \mathrm{L},<0.2-1.1 \mu \mathrm{g} / \mathrm{L}$ respectively) under the prevailing oxic conditions.

Values of TDS are generally higher than those found in the SCS springs (range 176$1130 \mathrm{mg} / \mathrm{L}$ ). Higher TDS values are found mainly but not exclusively in discharge zones. 
Giménez-Forcada, E.; Smedley, P.L. (2014). Geological factors controlling occurrence and distribution of arsenic in groundwaters from the southern margin of the Duero Basin, Spain. Environ Geochem Health. 36(6):1029-47.

DOI: 10.1007/s10653-014-9599-2

Concentrations of $\mathrm{NO}_{3}$ are often high (up to $206 \mathrm{mg} / \mathrm{L}$; Tables 2, 3b). Of the spring waters investigated, $88 \%$ exceed the $\mathrm{EC}$ and Spanish limit for $\mathrm{NO}_{3}$ in drinking water $(50 \mathrm{mg} / \mathrm{L})$. Occurrence of high concentrations, above the concentrations expected from natural soil reactions, are likely to result from pollution and evaporation. Concentrations of sulphate are also generally higher than in springs from SCS (4-158 $\mathrm{mg} / \mathrm{L}$, median $54 \mathrm{mg} / \mathrm{L}$ ); alkalinity is in the range $27-341 \mathrm{mg} / \mathrm{L}$, median $171 \mathrm{mg} / \mathrm{L}$.

The main hydrochemical facies of the DB springs is $\mathrm{Ca}_{-} \mathrm{HCO}_{3}(64 \%)$. Calcium (27$195 \mathrm{mg} / \mathrm{L}$, median $85 \mathrm{mg} / \mathrm{L}$ ) usually correlates well with magnesium (2-33 mg/L, median $17 \mathrm{mg} / \mathrm{L}$ ). Sodium has a range of $8-109 \mathrm{mg} / \mathrm{L}$ (median $38 \mathrm{mg} / \mathrm{L}$ ).

Arsenic concentrations in the springs lie in the range 1-63 $\mu \mathrm{g} / \mathrm{L}$ (median $12.4 \mathrm{\mu g} / \mathrm{L})$ and are spatially variable. Some high concentrations of uranium and vanadium are also observed (up to $55 \mu \mathrm{g} / \mathrm{L}$ and $19 \mu \mathrm{g} / \mathrm{L}$ respectively), consistent with the oxic conditions.

In the samples of groundwater from the boreholes, depths range from $23 \mathrm{~m}$ to $450 \mathrm{~m}$ (median $62 \mathrm{~m}$ ), and all are completed within the DB sedimentary aquifer. The main hydrochemical facies of the shallow borehole groundwater (to $160 \mathrm{~m}$ ) are Ca$\mathrm{HCO}_{3}(46 \%), \mathrm{Na}-\mathrm{HCO}_{3}(14 \%)$ and $\mathrm{Na}-\mathrm{Cl}(27 \%)$. For deep borehole groundwater $(>160 \mathrm{~m})$ the hydrochemical facies are $\mathrm{Na}-\mathrm{HCO}_{3}(60 \%)$ and $\mathrm{Na}-\mathrm{Cl}(40 \%)$ (Table 1; Figure 3). The borehole groundwaters are commonly though not always oxidising. They have variable saturation states with respect to calcite $\left(\mathrm{SI}_{\text {calcite }}-0.9-0.54\right)$, being most variable in shallow groundwaters ( $<40 \mathrm{~m}$ deep). Total dissolved solids range between 93 and 844 $\mathrm{mg} / \mathrm{L}$, the higher values resulting from evaporation under ambient semi-arid climatic conditions in the shallower boreholes.

Redox-sensitive elements have a large range of concentrations, though most reflect the dominance of oxic conditions in the borehole environment, particularly at shallower levels. Concentrations of $\mathrm{NO}_{3}$ reach up to $195 \mathrm{mg} / \mathrm{L}, 20 \%$ exceeding the $\mathrm{EC}$ and Spanish limit for nitrate in drinking water. The highest $\mathrm{NO}_{3}$ concentrations occur in boreholes with depth $<40 \mathrm{~m}$. The sample with the highest concentration also has a relatively high concentration of $\mathrm{NH}_{4}(0.32 \mathrm{mg} / \mathrm{L})$ and TOC $(8.1 \mathrm{mg} / \mathrm{L})$, suggestive of a pollutant origin. For the boreholes as a whole, concentrations of $\mathrm{NH}_{4}$ lie in the range $<0.1-2.9 \mathrm{mg} / \mathrm{L}$ and TOC values are $0.3-8.1 \mathrm{mg} / \mathrm{L}$. Phosphate as $\mathrm{PO}_{4}$ ranges from $<0.1$ to $0.5 \mathrm{mg} / \mathrm{L}$ and has no obvious depth relationship. Concentrations of dissolved Fe and $\mathrm{Mn}$ are $<0.01-0.84 \mathrm{mg} / \mathrm{L}$ and $<0.5-69 \mu \mathrm{g} / \mathrm{L}$ respectively.

Dissolved As concentration in the borehole groundwaters reaches $241 \mu \mathrm{g} / \mathrm{L}, 60 \%$ of samples exceeding the $10 \mu \mathrm{g} / \mathrm{L}$ EC drinking-water limit. Relatively high As concentrations $(>10 \mu \mathrm{g} / \mathrm{L})$ are found in shallow groundwaters $(<40 \mathrm{~m})$ but the highest are seen in deep (200-450 m) borehole waters. Here, arsenic concentrations of 90$241 \mu \mathrm{g} / \mathrm{L}$ are observed. A broad positive correlation with $\mathrm{pH}$ is observed (Figure 4). 
Giménez-Forcada, E.; Smedley, P.L. (2014). Geological factors controlling occurrence and distribution of arsenic in groundwaters from the southern margin of the Duero Basin, Spain. Environ Geochem Health. 36(6):1029-47.

DOI: $10.1007 /$ s10653-014-9599-2
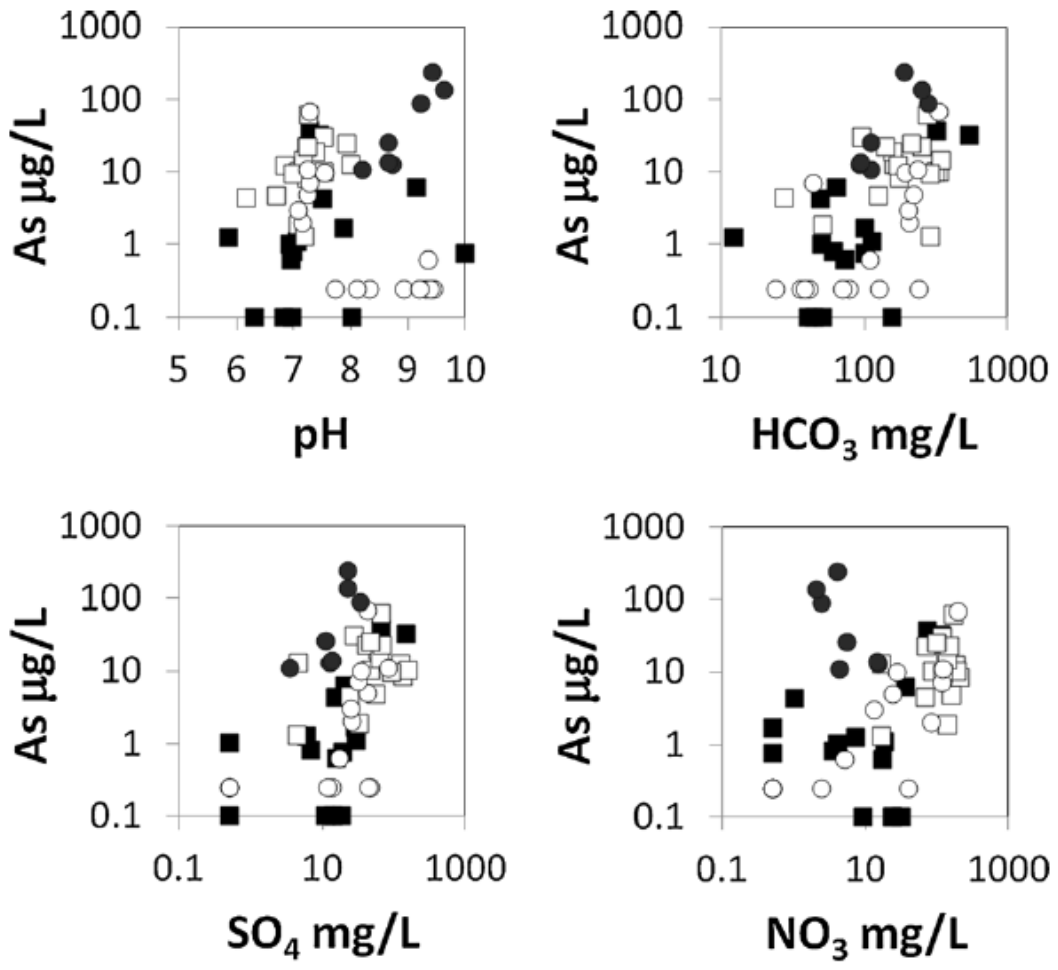

Figure 4. Relationship between $\mathrm{As}$ and $\mathrm{pH}, \mathrm{SO}_{4}, \mathrm{HCO}_{3}$ and $\mathrm{NO}_{3}$ in groundwaters from the SCS and DB (symbols as in Figure 3 legend).

The deepest boreholes, B1, B2 and $\mathrm{DpB}$, have groundwater $\mathrm{pH}$ values $>9$ (Figure 4) and samples $\mathrm{B} 1$ and $\mathrm{B} 2$ correspondingly contain $\mathrm{CO}_{3}$. Eh values (where measured) are $>400 \mathrm{mV}$ (Table 2), indicating oxic conditions. Concentrations of $\mathrm{NO}_{3}$ are in the 2-4 $\mathrm{mg} / \mathrm{L}$ range, which are low compared to the shallow groundwaters, but still indicative of oxic conditions. Other trace anion and oxyanion species also have relatively high concentrations in these groundwaters. Concentrations of fluoride are in the range 2-3 $\mathrm{mg} / \mathrm{L}$ (Table 2). For boreholes B1 and B2 where trace-anion data are available, concentrations are respectively: uranium $(30 \mu \mathrm{g} / \mathrm{L}, 12 \mu \mathrm{g} / \mathrm{L})$, vanadium $(64 \mu \mathrm{g} / \mathrm{L}$, $48 \mu \mathrm{g} / \mathrm{L})$, boron (190 $\mu \mathrm{g} / \mathrm{L}, 113 \mu \mathrm{g} / \mathrm{L})$ and molybdenum $(1.7 \mu \mathrm{g} / \mathrm{L}, 1.0 \mu \mathrm{g} / \mathrm{L})$.

\subsection{Arsenic species}

Figure 5a illustrates the thermodynamically predicted arsenic speciation for SCS and DB springs and for borehole $\mathrm{B} 1$ and $\mathrm{B} 2$, in an $\mathrm{Eh}-\mathrm{pH}$ diagram for aqueous As species in the system As- $\mathrm{O}_{2}-\mathrm{H}_{2} \mathrm{O}$ at $25^{\circ} \mathrm{C}$ and 1 bar total pressure (Brookins, 1988; Smedley and Kinniburgh 2002). A dominance of $A s(V)$ is indicated for all samples represented, although spring samples $\mathrm{Hp}$ and $\mathrm{Ls}$ (in which As concentration is below detection limit) lie close to the $A s(I I I)$ field and the uncertainty in speciation is greatest for these samples. The most thermodynamically stable $\mathrm{As}(\mathrm{V})$ species predicted for the $\mathrm{pH}$ and $\mathrm{Eh}$ ranges of the groundwater are $\mathrm{HAsO}_{4}{ }^{2-}$ and, to a lesser extent, $\mathrm{H}_{2} \mathrm{AsO}_{4}{ }^{-}$. A variation can 
Giménez-Forcada, E.; Smedley, P.L. (2014). Geological factors controlling occurrence and distribution of arsenic in groundwaters from the southern margin of the Duero Basin, Spain. Environ Geochem Health. 36(6):1029-47.

DOI: 10.1007/s10653-014-9599-2

be observed from acidic and more oxic waters (recharge areas in SCS) to alkaline and less oxidising waters (discharge areas in DB). The samples B1 and B2 are strongly alkaline and oxic, and have the highest observed As concentrations.

$\mathbf{a}$

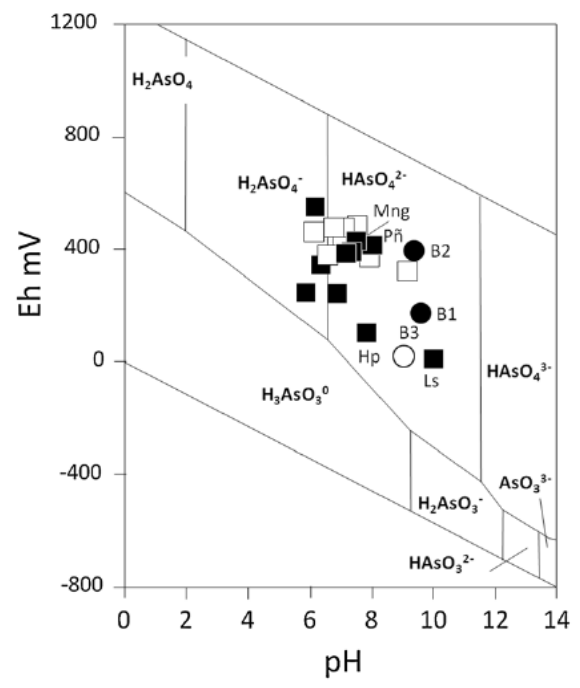

b

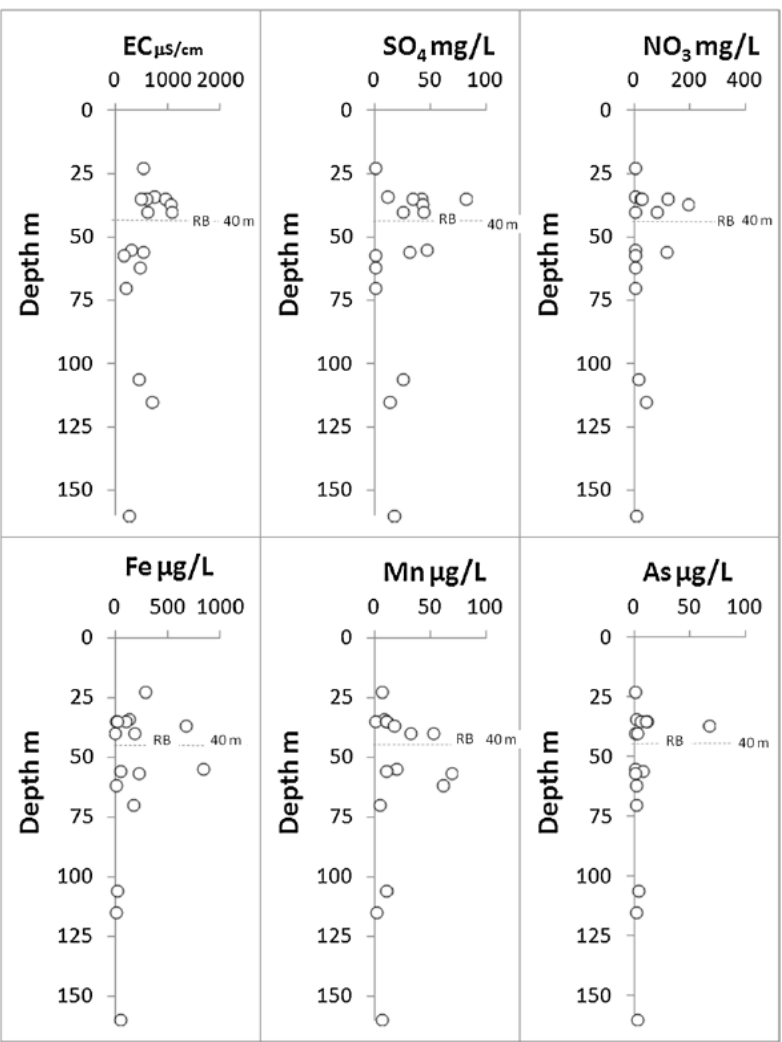

Figure 5. (a) Eh-pH diagram for aqueous $A s$ species in the system $A s-O_{2}-H_{2} \mathrm{O}$ at $25^{\circ} \mathrm{C}$ and 1 bar total pressure (Smedley and Kinniburgh 2002); showing SCS springs, DB springs and boreholes B1 and B2. (symbols as in Figure 3). (b) Variation of several parameters with depth for shallow sedimentary boreholes (depths $<160 \mathrm{~m}$ ); RB (approximate redox boundary position according hydrochemical data 
Giménez-Forcada, E.; Smedley, P.L. (2014). Geological factors controlling occurrence and distribution of arsenic in groundwaters from the southern margin of the Duero Basin, Spain. Environ Geochem Health. 36(6):1029-47.

DOI: 10.1007/s10653-014-9599-2

These observations are supported by As speciation data from boreholes B1, B2 and $\mathrm{B} 3$ (Table $3 \mathrm{c}$ ). These have $\mathrm{As}(\mathrm{III}) / \mathrm{As}_{\mathrm{T}}$ ratios of $0.02,0.09$ and 0.22 respectively. Oxic groundwater from boreholes B1 and B2 with high concentrations of As $(138 \mu \mathrm{g} / \mathrm{L}$, $241 \mu \mathrm{g} / \mathrm{L}$ respectively) are clearly dominated by $\mathrm{As}(\mathrm{V})$. The more reducing groundwater from borehole B3, with a lower concentration of As, has a higher proportion of As(III). Organic As species were undetected.

Table 3a

Summary statistical data for analytes in spring waters taken in the Spanish Central System.

\begin{tabular}{|c|c|c|c|c|c|c|c|c|c|}
\hline Component & Units & Min & Max & Median & Mean ${ }^{*}$ & $\begin{array}{l}\text { Standard } \\
\text { Deviation }\end{array}$ & 10th centile & 90th centile & n \\
\hline Altitude & $\mathrm{m}$ & 989 & 1536 & 1054 & 1118 & 155 & 995 & 1465 & 11 \\
\hline Eh & $\mathrm{mV}$ & 17.4 & 473 & 354 & 314 & 143 & 36.9 & 469 & 11 \\
\hline $\mathrm{T}$ & ${ }^{\circ} \mathrm{C}$ & 5.70 & 20.5 & 11.0 & 10.98 & 4.06 & 6.00 & 18.2 & 15 \\
\hline SEC & $\mu \mathrm{S} \mathrm{cm} \mathrm{cm}^{-1}$ & 85.6 & 1563 & 231 & 375 & 399 & 95.0 & 1242 & 15 \\
\hline $\mathrm{pH}$ & units & 5.85 & 9.98 & 7.05 & 7.40 & 1.04 & 6.13 & 9.48 & 15 \\
\hline TDS & $\mathrm{mg} \mathrm{l}^{-1}$ & 38 & 1266 & 159 & 269 & 318 & 61 & 932 & 15 \\
\hline $\mathrm{Ca}$ & $\mathrm{mg} \mathrm{I}^{-1}$ & $<1$ & 130 & 15.0 & 29.9 & 40.9 & 0.600 & 124 & 15 \\
\hline $\mathrm{Mg}$ & $\mathrm{mg} \mathrm{l}^{-1}$ & 1.00 & 66.8 & 5.00 & 9.95 & 16.6 & 0.88 & 39.8 & 15 \\
\hline $\mathrm{Na}$ & $\mathrm{mg} \mathrm{l}^{-1}$ & 6.00 & 106 & 15.0 & 28.7 & 30.7 & 7.15 & 95.6 & 15 \\
\hline K & $\mathrm{mg} \mathrm{I}^{-1}$ & $<1$ & 25.1 & 1.00 & 3.33 & 6.22 & 0.500 & 13.3 & 15 \\
\hline $\mathrm{HCO}_{3}$ & $\mathrm{mg} \mathrm{I}^{-1}$ & 12 & 532 & 63.0 & 117 & 136 & 28.8 & 403 & 15 \\
\hline $\mathrm{Cl}$ & $\mathrm{mg} \mathrm{l}^{-1}$ & 3.00 & 147 & 13.0 & 29.6 & 38.6 & 3.40 & 102 & 15 \\
\hline $\mathrm{SO}_{4}$ & $\mathrm{mg} \mathrm{I}^{-1}$ & $<1$ & 148 & 15.3 & 26.3 & 37.1 & 0.000 & 98.0 & 15 \\
\hline $\mathrm{NO}_{3}$ & $\mathrm{mg} \mathrm{l}^{-1}$ & $<0.5$ & 113 & 16.8 & 23.9 & 31.0 & 0.25 & 88.6 & 15 \\
\hline $\mathrm{F}$ & $\mathrm{mg} \mathrm{l}^{-1}$ & $<0.05$ & 14.24 & 0.025 & 1.99 & 4.55 & 0.009 & 12.8 & 11 \\
\hline $\mathrm{SiO}_{2}$ & $\mathrm{mg} \mathrm{l}^{-1}$ & 13.20 & 34.3 & 25.4 & 24.1 & 7.22 & 13.8 & 33.7 & 11 \\
\hline $\mathrm{Sr}$ & $\mu g I^{-1}$ & $<10$ & 1310 & 63.6 & 279 & 395 & 5.00 & 999 & 15 \\
\hline $\mathrm{Mn}$ & $\left.\mu g\right|^{-1}$ & 0.030 & 39.7 & 0.805 & 6.02 & 12.9 & 0.039 & 35.6 & 12 \\
\hline $\mathrm{Fe}_{\mathrm{T}}$ & $\left.\mu g\right|^{-1}$ & $<15$ & 734 & 10.0 & 93.9 & 240 & 3.00 & 734 & 9 \\
\hline $\mathrm{Li}$ & $\left.\mu g\right|^{-1}$ & $<0.05$ & 137 & 0.260 & 16.6 & 35.7 & 0.025 & 81.2 & 15 \\
\hline B & $\left.\mu g\right|^{-1}$ & $<10$ & 135 & 50.0 & 52.5 & 41.5 & 5.00 & 135 & 9 \\
\hline As & $\mu g I^{-1}$ & 0.09 & 37.6 & 1.02 & 5.90 & 12.0 & 0.126 & 34.5 & 15 \\
\hline U & $\left.\mu g\right|^{-1}$ & 0.002 & 21.4 & 0.190 & 6.38 & 9.47 & 0.002 & 21.4 & 5 \\
\hline
\end{tabular}

\section{Discussion}

\subsection{Groundwater from springs}

As observed in previous studies of spring waters in Ávila province, the concentration of arsenic generally is higher in groundwater from the DB aquifer than in the SCS basement (Giménez-Forcada et al., 2010a,b).

The highest values of arsenic in spring waters collected from the SCS are found in two springs located very close to the DB contact, in the locations of Peñalba (Pñ) and Mingorría (Mng). These are oxidising (Eh values $390 \mathrm{mV}$ and $397 \mathrm{mV}$ respectively) Ca$\mathrm{HCO}_{3}$ waters. They also have relatively high concentrations of uranium and vanadium, with uranium concentrations reaching among the largest observed in the spring-water dataset $(21.4 \mu \mathrm{g} / \mathrm{L})$. These can be considered dissolved species since the concentrations of Fe and Al are low (each less than $10 \mu \mathrm{g} / \mathrm{L}$ ) and the colloidal contribution therefore negligible. 
Giménez-Forcada, E.; Smedley, P.L. (2014). Geological factors controlling occurrence and distribution of arsenic in groundwaters from the southern margin of the Duero Basin, Spain. Environ Geochem Health. 36(6):1029-47.

DOI: $10.1007 /$ s10653-014-9599-2

\begin{tabular}{|c|c|c|c|c|c|c|c|c|}
\hline Component & Units & Min & Max & Median & Mean ${ }^{*}$ & $\begin{array}{l}\text { Standard } \\
\text { deviation }\end{array}$ & 10th centile & 90th centile \\
\hline Altitude & $\mathrm{m}$ & 807 & 1032 & 915 & 909 & 65.9 & 818 & 1022 \\
\hline Eh & $\mathrm{mV}$ & 386 & 484 & 409 & 429 & 36.6 & 389 & 483 \\
\hline $\mathrm{pH}$ & units & 6.15 & 7.99 & 7.22 & 7.20 & 0.43 & 6.58 & 7.93 \\
\hline SEC & $\mu \mathrm{S} \mathrm{cm}^{-1}$ & 176 & 1133 & 528 & 610 & 262 & 255 & 983 \\
\hline $\mathrm{Ca}$ & $\mathrm{mg} \mathrm{l}^{-1}$ & 27 & 195 & 85.2 & 92.5 & 45.8 & 32.9 & 148 \\
\hline $\mathrm{Mg}$ & $\mathrm{mgl}^{-1}$ & 1.83 & 32.9 & 16.9 & 17.1 & 8.57 & 5.01 & 29.4 \\
\hline $\mathrm{Na}$ & $m g I^{-1}$ & 8.20 & 109 & 38.4 & 43.3 & 25.1 & 14.8 & 82.7 \\
\hline K & $\mathrm{mgl}^{-1}$ & 2.02 & 38.7 & 5.82 & 9.32 & 9.6 & 2.06 & 29.9 \\
\hline $\mathrm{HCO}_{3}$ & $m g I^{-1}$ & 27.2 & 341 & 172 & 199 & 96.5 & 46.3 & 330 \\
\hline $\mathrm{CO}_{3}$ & $\mathrm{mgl}^{-1}$ & $<1$ & $<1$ & - & - & - & - & - \\
\hline $\mathrm{Cl}$ & $m g I^{-1}$ & 11.2 & 170 & 45.8 & 68.7 & 49.5 & 14.6 & 153 \\
\hline $\mathrm{SO}_{4}$ & $\mathrm{mgl}^{-1}$ & 4.33 & 158 & 54.1 & 61.4 & 43.5 & 4.53 & 138 \\
\hline $\mathrm{NO}_{3}$ & $\mathrm{mgl}^{-1}$ & 16.3 & 206 & 132 & 119 & 55.0 & 16.5 & 190 \\
\hline $\mathrm{F}$ & $m g I^{-1}$ & 0.07 & 0.49 & 0.26 & 0.26 & 0.12 & 0.08 & 0.41 \\
\hline $\mathrm{SiO}_{2}$ & $\mathrm{mgl}^{-1}$ & 9.99 & 52.3 & 36.8 & 36.1 & 13.2 & 11.7 & 51.9 \\
\hline $\mathrm{Sr}$ & $\left.\mu g\right|^{-1}$ & 179 & 1893 & 652 & 801 & 507 & 252 & 1733 \\
\hline $\mathrm{Mn}$ & $\left.\mu g\right|^{-1}$ & $<0.2$ & 1.10 & 0.10 & 0.30 & 0.30 & 0.10 & 0.94 \\
\hline $\mathrm{Fe}_{\mathrm{T}}$ & $\mu g \mathrm{I}^{-1}$ & $<1$ & 11.0 & 2.00 & 2.53 & 2.80 & 0.50 & 8.60 \\
\hline $\mathrm{Li}$ & $\left.\mu g\right|^{-1}$ & 1.00 & 99.0 & 33.0 & 37.3 & 24.0 & 9.00 & 78.2 \\
\hline B & $\mu g I^{-1}$ & $<10$ & 58.0 & 5.00 & 9.06 & 12.9 & 5.00 & 22.0 \\
\hline As & $\mu g \mathrm{I}^{-1}$ & 1.32 & 62.5 & 12.4 & 16.2 & 14.7 & 1.76 & 37.4 \\
\hline V & $\left.\mu g\right|^{-1}$ & 0.20 & 18.7 & 6.30 & 7.25 & 4.97 & 2.04 & 15.0 \\
\hline $\mathrm{Se}$ & $\mu \mathrm{g}^{-1}$ & 0.20 & 1.60 & 0.70 & 0.75 & 0.42 & 0.20 & 1.44 \\
\hline w & $\mu \mathrm{g}^{-1}$ & 0.03 & 4.24 & 0.05 & 0.36 & 1.01 & 0.03 & 1.33 \\
\hline u & $\left.\mu \mathrm{g}\right|^{-1}$ & 0.03 & 54.91 & 10.2 & 11.1 & 13.0 & 0.05 & 26.2 \\
\hline
\end{tabular}

Reducing conditions occur in a minority of springs taken in SCS, as shown by 'La Salud' $(L s)$ and 'Huevos podridos' (Hp) springs (Figure $1 \mathrm{~b}$ ). In these, $\mathrm{pH}$ values are alkaline and the water is of $\mathrm{Na}-\mathrm{HCO}_{3}$ type. In both reducing springs, dissolved arsenic concentrations below detection limit and low $\mathrm{SO}_{4}$ concentrations can be explained by sulphate-reducing conditions favouring production of solid iron sulphide, with resultant instability of dissolved As (Lowers et al., 2007).

In the SCS sector, spring waters are distributed linearly in association with the main family of faults (NE-SW, E-W, and NW-SE). The occurrence of arsenic is likely linked to weathering of vein-hosted sulphide mineralisation identified in the SCS range. Release from these arsenic-bearing sulphide minerals by oxidation is a likely process for generating dissolved As (e.g. Schreiber et al., 2003; Appleyard et al., 2006).

The influence of the crystalline basement in the general chemistry of DB groundwater is evidenced by the springs located along the extensions of fault lines within the Cenozoic sediments (Figure 6). For DB springs, carbonate and silicate weathering reactions generate the major-ion compositions observed, along with alkaline $\mathrm{pH}$ values. Trace elements that commonly accumulate in water through silicate and carbonate weathering reactions, such as Si (median $17 \mu \mathrm{g} / \mathrm{L}$ ), Li (median $33 \mu \mathrm{g} / \mathrm{L}$ ), 
Giménez-Forcada, E.; Smedley, P.L. (2014). Geological factors controlling occurrence and distribution of arsenic in groundwaters from the southern margin of the Duero Basin, Spain. Environ Geochem Health. 36(6):1029-47.

DOI: 10.1007/s10653-014-9599-2

Ba (median $117 \mu \mathrm{g} / \mathrm{L}$ ), and $\mathrm{Sr}$ (median $652 \mu \mathrm{g} / \mathrm{L}$ ), show good inter-element positive correlations ( $r$ for Ba-Sr 0.88; Si-Ba 0.64; Li-Sr 0.85; Si-Sr 0.73).

\begin{tabular}{|c|c|c|c|c|c|c|c|c|c|}
\hline Component & Units & Min & Max & Median & Mean ${ }^{*}$ & $\begin{array}{l}\text { Standard } \\
\text { Deviation }\end{array}$ & 10 th centile & 90th centile & $n$ \\
\hline Well depth & $\mathrm{m}$ & 23 & 450 & 62 & 134 & 129 & 34 & 380 & 23 \\
\hline Temperature & ${ }^{\circ} \mathrm{C}$ & 10 & 25 & 15 & 15 & 4 & 10 & 19 & 22 \\
\hline SEC & $\mu \mathrm{S} \mathrm{cm}-1$ & 165 & 1066 & 497 & 524 & 252 & 216 & 1013 & 23 \\
\hline $\mathrm{pH}$ & units & 7.07 & 9.62 & 8.64 & 8.39 & 0.90 & 7.18 & 9.43 & 23 \\
\hline TDS & $\mathrm{mg} \mathrm{l}^{-1}$ & 93 & 844 & 328 & 354 & 178 & 135 & 643 & 23 \\
\hline $\mathrm{HCO}_{3}$ & $\mathrm{mg} \mathrm{l}^{-1}$ & 23.8 & 330 & 109 & 143 & 89 & 37 & 266 & 23 \\
\hline $\mathrm{Cl}$ & $\mathrm{mg} \mathrm{l}^{-1}$ & 13.5 & 262 & 26 & 55 & 63 & 15 & 171 & 23 \\
\hline $\mathrm{SO}_{4}$ & $\mathrm{mg} \mathrm{l}^{-1}$ & $<1$ & 82 & 22 & 23 & 20 & 1 & 45 & 23 \\
\hline $\mathrm{NO}_{3}$ & $\mathrm{mg} \mathrm{I}^{-1}$ & $<1$ & 195 & 5 & 29 & 51 & 1 & 118 & 23 \\
\hline $\mathrm{Ca}$ & $\mathrm{mg} \mathrm{l}^{-1}$ & $<1$ & 137 & 13 & 36 & 40 & 1 & 100 & 23 \\
\hline $\mathrm{Mg}$ & $\mathrm{mg} \mathrm{l}^{-1}$ & $<1$ & 42 & 7 & 9 & 11 & 1 & 27 & 23 \\
\hline $\mathrm{Na}$ & $\mathrm{mg} \mathrm{l}^{-1}$ & 7 & 139 & 38 & 54 & 39 & 15 & 124 & 23 \\
\hline K & $\mathrm{mg} \mathrm{l}^{-1}$ & $<1$ & 49.9 & 1.4 & 3.8 & 10.2 & 0.5 & 5.2 & 23 \\
\hline $\mathrm{F}$ & $\mathrm{mg} \mathrm{l}^{-1}$ & $<0.5$ & 3.0 & 0.3 & 0.6 & 0.9 & 0.1 & 2.4 & 23 \\
\hline $\mathrm{Mn}$ & $\mu \mathrm{g} \mathrm{I}^{-1}$ & $<0.5$ & 69.0 & 6.5 & 14.6 & 19.9 & 0.6 & 57.8 & 23 \\
\hline $\mathrm{Fe}_{\mathrm{T}}$ & $\mu \mathrm{g}^{-1}$ & $<10$ & 840 & 50 & 140 & 210 & 5 & 520 & 23 \\
\hline As & $\left.\mu g\right|^{-1}$ & $<0.5$ & 241 & 5.0 & 27.9 & 57.7 & 0.0 & 119 & 23 \\
\hline $\mathrm{NH}_{4}$ & $\mathrm{mg} \mathrm{I}^{-1}$ & $<0.05$ & 2.9 & 0.1 & 0.5 & 0.9 & 0.0 & 2.4 & 23 \\
\hline $\mathrm{NO}_{2}$ & $\mathrm{mg} \mathrm{l}^{-1}$ & $<0.05$ & 0.1 & 0.0 & 0.0 & 0.0 & 0.0 & 0.1 & 23 \\
\hline TOC & $\mathrm{mg} \mathrm{l}^{-1}$ & 0.25 & 8.1 & 0.9 & 1.2 & 1.5 & 0.6 & 1.6 & 23 \\
\hline AsIll & $\mu g I^{-1}$ & 0.5 & 12.5 & 5.9 & 6.3 & 6.0 & 0.5 & 12.5 & 3 \\
\hline AsV & $\mu \mathrm{gl}^{-1}$ & 1.8 & 235 & 126 & 121 & 117 & 1.8 & 235 & 3 \\
\hline
\end{tabular}

Non-detects treated as half-detection-limit values.

In the DB spring waters, concentrations of As, $U$ and $V$ are often relatively high although the correlations between them are weak (Pearson's correlation for As-V 0.20, As-U 0.11, V-U 0.36). Uranium shows a general positive correlation with alkalinity ( $r$ value for $\mathrm{U}-\mathrm{HCO}_{3}$ 0.62). The overall elevated concentrations $\mathrm{As}, \mathrm{V}$ and $\mathrm{U}$ are consistent with the observations made by Sahún et al. (2004) and Gómez et al. (2006) in previous studies of the DB. These elements are stabilised in soluble form under oxic conditions as arsenate, vanadate and uranyl carbonate species (Langmuir, 1978; Smedley et al., 2005; Naeem et al., 2007). Around $6 \%$ of analysed samples collected in DB have U concentrations in excess of the WHO (2011) provisional guideline value for $U$ in drinking water of $30 \mu \mathrm{g} / \mathrm{L}$. Desorption of these trace elements from metal oxides and stabilisation in anionic and oxyanionic form under the ambient high-pH and oxic conditions is considered a likely process for release into solution. Ferric and aluminium are known to be disseminated in the sediments (Armenteros et al., 2002; Gómez et al., 2004; and Sahún et al., 2004). Additional recorded minerals in these aquifers include authigenic pyrite, iron-titanium oxides, authigenic illite, detrital grains of white mica, biotite and organomineral compounds, and these represent potential primary sources of these trace elements (Appelo and Postma, 2006; Seddique et al., 2008; Masuda et al., 2010). 
Giménez-Forcada, E.; Smedley, P.L. (2014). Geological factors controlling occurrence and distribution of arsenic in groundwaters from the southern margin of the Duero Basin, Spain. Environ Geochem Health. 36(6):1029-47.

DOI: 10.1007/s10653-014-9599-2

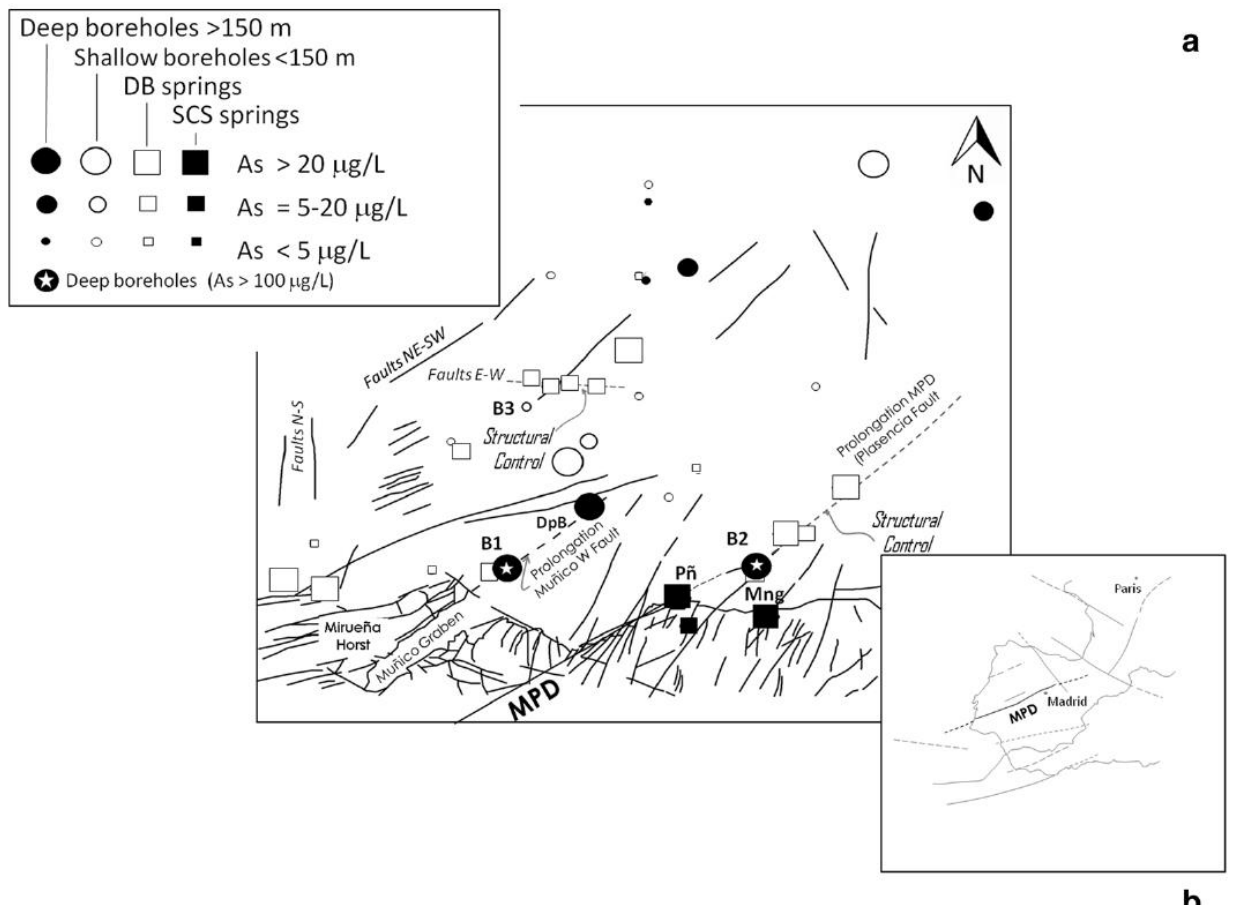

b
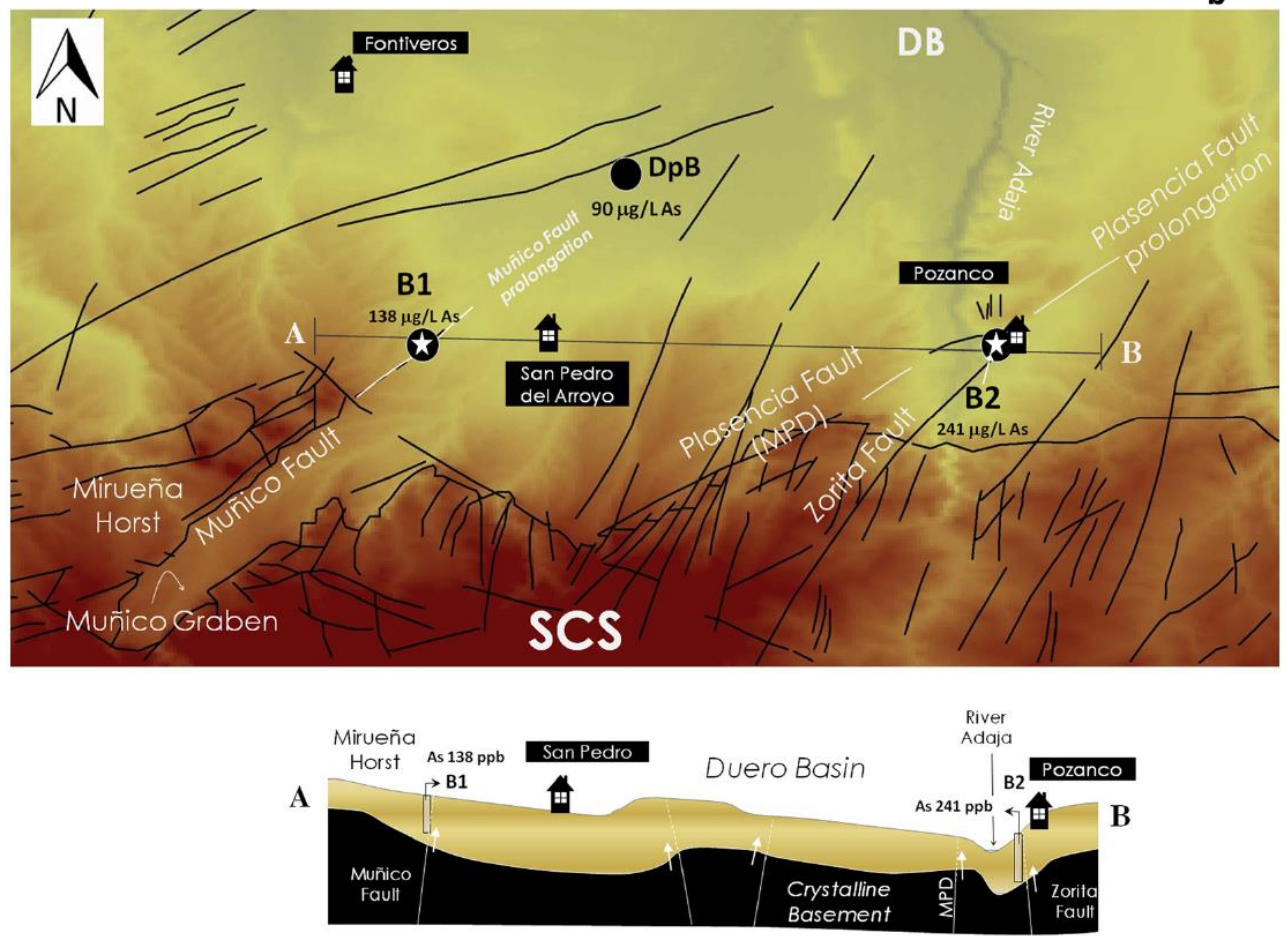

- Sedimentary deep boreholes B1 and B2 (As> $100 \mu \mathrm{g} / \mathrm{L})$

Figure 6. (a) Arsenic distribution in DB springs and boreholes in relation to the main fractures mapped by Simón (1996). (b) Topography of the area between Muñico Graben and Messejana-Plasencia dyke (Plasencia fault). The fault lines correspond to those mapped by Simón (1996). Deep boreholes B1 and B2 with the highest As concentrations are represented in a small cross sections. 
Giménez-Forcada, E.; Smedley, P.L. (2014). Geological factors controlling occurrence and distribution of arsenic in groundwaters from the southern margin of the Duero Basin, Spain. Environ Geochem Health. 36(6):1029-47.

DOI: 10.1007/s10653-014-9599-2

\subsection{Groundwater from boreholes}

Arsenic-contaminated groundwater from the boreholes in the DB is also mainly associated with oxic and alkaline conditions, and as for the springs, arsenic release can be explained by desorption from metal oxides, as well as potentially from primary silicate minerals and sulphide ores.

Although factors such as $\mathrm{pH}$ and redox conditions play important roles in controlling the occurrence, distribution and mobility of arsenic in the groundwaters, the basement structure also exerts a significant control. The groundwater flow system in DB is influenced by the configuration of faults, which act as preferential flow zones in tectonic depressions (Vilanova et al., 2008), particularly those faults whose direction coincides with general flow path in the basin. In addition, horst and graben structures, orientated mainly NE-SW and E-W, can generate discrete hydrogeological cells.

Large variations in chemical quality occur in the aquifer, both spatially and with depth. In the shallow sedimentary aquifer $(<40 \mathrm{~m})$, evaporation appears to be an important factor. Evaporation can increase the concentrations of analytes including trace elements in the residual waters (e.g. Fujii and Swain, 1995; Welch and Lico, 1998; Smedley and Kinniburgh, 2002). The presence of soluble evaporite minerals may also enhance solute concentrations, although the distribution of evaporites within this sector of DB is noted to be limited.

Figure 5b shows trends in some solutes with depth for all samples from the study area for which depth information is available. For the shallow wells $(<40 \mathrm{~m})$, pollution, oxidising conditions and evaporation are likely factors controlling chemical composition. At $40-160 \mathrm{~m}$ depth, reducing conditions can be important in some samples and can affect the concentrations of As, as well as other redox-sensitive analytes $\left(\mathrm{SO}_{4}, \mathrm{NO}_{3}, \mathrm{Fe}\right.$ and $\mathrm{Mn}$; Figure $\left.5 \mathrm{~b}\right)$. The low concentrations of As observed at depth are consistent with As substitution into neoforming sulphide minerals under reducing conditions.

In deeper boreholes within the sedimentary aquifer $(200-450 \mathrm{~m})$, the dominant waters are sodium-bicarbonate facies with alkaline $\mathrm{pH}(>9)$ and high values of arsenic (up to $241 \mu \mathrm{g} / \mathrm{L}$ ), associated with an oxidising environment. The most plausible hypothesis to explain this composition is the contribution of oxidising flows following the main direction of faults in DB. Faults behave as effective conduits for groundwater flow and influence the recharge of the basin. These deep flow paths (coming directly from the basement and also through the discontinuities within the sedimentary basin) can also transport dissolved As from As-enriched zones in the SCS, potentially enhanced from the DB sediments, under oxic and alkaline groundwater conditions.

Basement structure consists of an alternation of horsts and grabens, associated with late or post Variscan tectonism, the main fault orientations of which are NE-SW, $\mathrm{N} 0^{\circ}-10^{\circ} \mathrm{E}$, and $\mathrm{N} 80^{\circ}-90^{\circ} \mathrm{E}$ (Ubanell, 1985; Ares et al., 1995; Simon, 1996; Babín and Gómez, 1997; Herrero, 1999). These structures have their manifestation on the 
Giménez-Forcada, E.; Smedley, P.L. (2014). Geological factors controlling occurrence and distribution of arsenic in groundwaters from the southern margin of the Duero Basin, Spain. Environ Geochem Health. 36(6):1029-47.

DOI: 10.1007/s10653-014-9599-2

basement surface as large lineaments or areas with a high density of smaller lineaments. The structural forms have determined subsequent sedimentation and lithological discontinuities (Colmenero et al. 2001; Armenteros et al. 2002; AlonsoGavilán et al. 2004). These in turn control the hydrogeological and hydrochemical features in the basin (Marchán-Sanz et al., 2010).

The major fault structures appear to control the occurrence of dissolved arsenic in the groundwaters in this area of DB (Figure 6a). The clearest example is given by groundwaters extracted from the deepest boreholes DpB, B1 and B2, which have been drilled along the main fault lines, taking advantage of the direction of preferential recharge flows. These oxidising, alkaline, sodium-bicarbonate-dominated flows have relatively high concentrations of $A s, U, V$ and $F$, and (albeit with limited data) appear to have high percentages of $\mathrm{As}(\mathrm{V})$.

Figure $6 \mathrm{~b}$ shows the location of the three boreholes with highest arsenic concentration, and their location with respect to the main faults, together with a cross section showing structural control. One of the boreholes (DpB) represents deep flows (90 $\mu \mathrm{g} / \mathrm{L} \mathrm{As}$; MAGRAMA database). A concentration of $138 \mu \mathrm{g} / \mathrm{L}$ As is found in the deep borehole B1, drilled in the prolongation of Muñico Fault, and $241 \mu \mathrm{g} / \mathrm{L}$ As in borehole B2, near the junction between Zorita Fault and Messejana-Plasencia Dyke (known as Plasencia Fault when it reaches DB). All these boreholes have been drilled within the sedimentary filling of DB. Plotting the piezometric surface reveals that both are within lines of preferential flow (Figure 7). Borehole B2 is an artesian borehole drilled in the vicinity of the prolongation of the Messejana-Plasencia dyke (MPD), which can be considered as a very important path flow system, where the oxic recharge water seems to travel long distances rapidly, providing waters enriched in arsenic. The interpretation of Figure 7, showing the distribution of dissolved As in relation to the main structures of the area, provides an explanation for the patchy distribution of arsenic in the groundwaters of the study area. The maximum observed values are concentrated at the prolongation of Mirueña Horst and of the MPD and Zorita Fault. In both cases, the basin fill is thin, and the influence of crystalline basement structures therefore greater. These horsts have been denominated as areas of high As, relating to structural control in an oxidising environment ('OE-SC'; Figure 7). Conversely, lower As concentrations $(<5 \mu \mathrm{g} / \mathrm{L})$ are located in the depressed areas on both sides of prolongation of Mirueña Horst (one corresponds to the prolongation of Muñico Graben; Figure 7). Reducing conditions appear to be responsible. Such conditions, as evidenced by low concentrations of $\mathrm{SO}_{4}$ and $\mathrm{NO}_{3}$, and highest $\mathrm{As}(\mathrm{III}) / \mathrm{As}_{\mathrm{T}}$ ratio (borehole B3 0.22 ) are consistent with sulphate reduction, likely microbially mediated. This can result in precipitation of solid sulphide minerals with consequent sequestration of As (low-As, reducing environment, deep control, 'RE-DC'; Figure 7). In several locations in this sector, relevant clayey horizons can be identified in the upper 100-150 m (ITGE, 1995), which could be responsible of slower flows and reducing conditions, particularly in sub-basin areas. 
Giménez-Forcada, E.; Smedley, P.L. (2014). Geological factors controlling occurrence and distribution of arsenic in groundwaters from the southern margin of the Duero Basin, Spain. Environ Geochem Health. 36(6):1029-47.

DOI: $10.1007 /$ s10653-014-9599-2

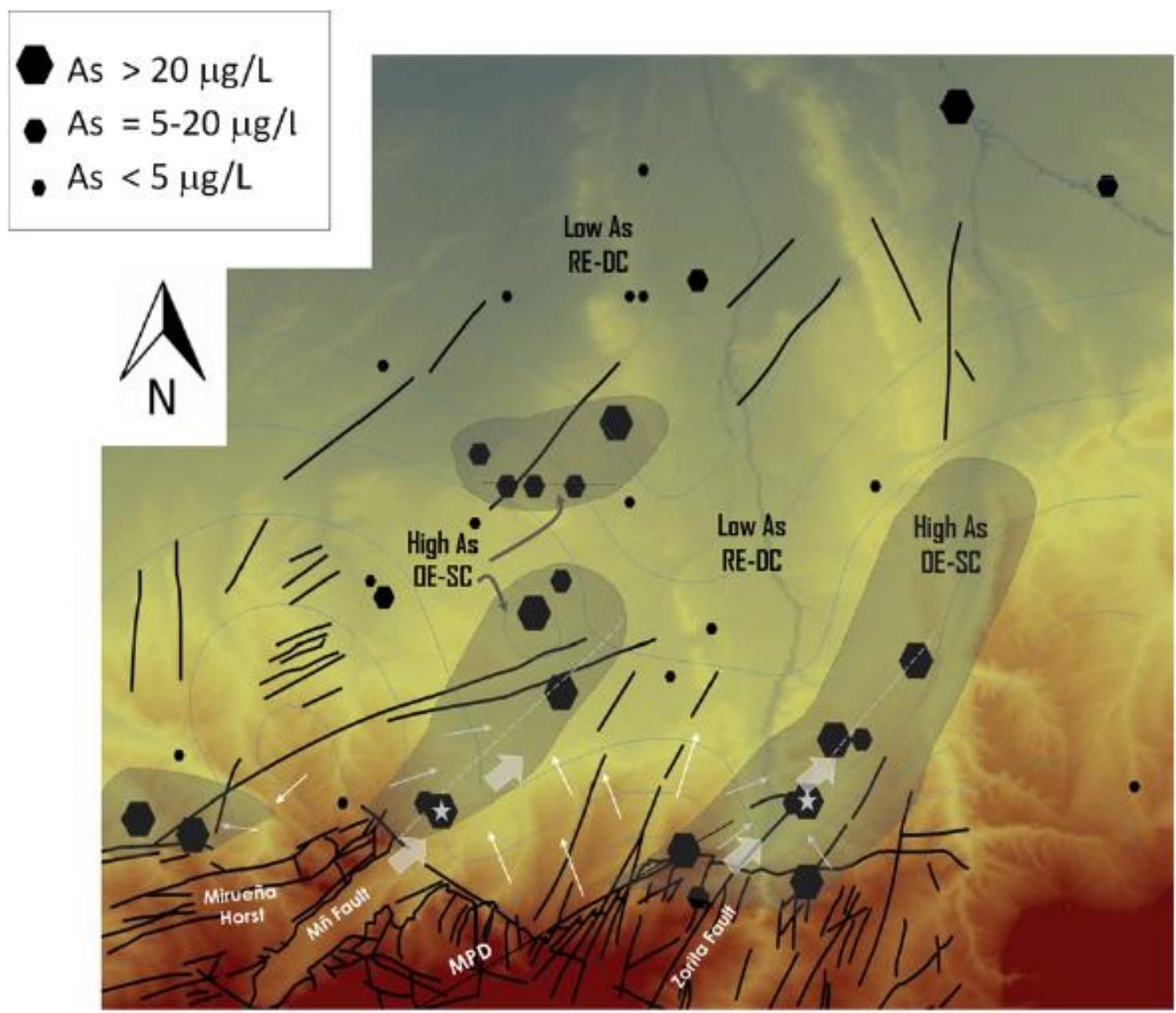

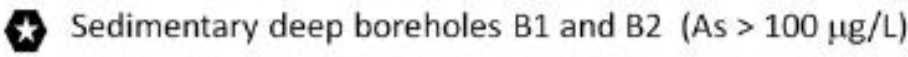

DE-SC Oxidising Environment-Structural Control RE-DC Reducing Environment- Deep Control

Figure 7. Arsenic distribution in groundwaters from the study area, adjacent to the main fractures. Blue contours indicate the piezometric surface. Symbol size reflects arsenic concentration.

The MPD-Zorita Fault and Muñico Fault must be considered as significant As inputs, capable of collecting and transmitting rapid flows and maintaining the oxygenated character of the recharged water. This natural groundwater flow regime is probably influenced further by flow induced by exploitation of boreholes drilled in the zone of influence of the faults.

\section{Conclusions}

The occurrence of arsenic in groundwaters from the southern margin of the Duero Basin is variable spatially and with depth. Relatively high concentrations of dissolved As 
Giménez-Forcada, E.; Smedley, P.L. (2014). Geological factors controlling occurrence and distribution of arsenic in groundwaters from the southern margin of the Duero Basin, Spain. Environ Geochem Health. 36(6):1029-47.

DOI: 10.1007/s10653-014-9599-2

occur under oxic and alkaline conditions (pH 7-9.6) and the high concentrations are often accompanied by relatively high concentrations of $U, V$ and $F$. Oxic and alkaline conditions occur both at shallow levels in springs and in boreholes at deeper levels (200-450 $\mathrm{m}$ depth) in the DB. The three-dimensional distributions of As in the DB are strongly controlled by basin structure. Basin morphology, prolongation of faults within the DB, particularly division of the underlying basement into blocks at its base, produces discrete hydrodynamic environments which result in spatial variations in hydrochemical composition. Fault zones with high permeability are particularly important preferential flow paths for oxic recharge water.

Under the oxidising conditions present in large parts of the DB aquifer, the mobility of As (as arsenate), is most likely promoted by desorption from metal oxyhydroxides in the sediments under high-pH conditions generated as a result of carbonate (and silicate reactions) in the sedimentary aquifer. Primary sulphides in the basement rocks however, are concluded to have been the primary mineral source.

In depressed areas, at levels deeper than about $40 \mathrm{~m}$, reducing conditions indicated by low concentrations of dissolved $\mathrm{SO}_{4}$, generate correspondingly low concentrations of dissolved As. These are likely the result of As removal coincident with the neoformation of iron sulphides.

The results of this study can be of value to improve the management of groundwater resources in the area and perhaps in other sectors of DB where the problem is more severe.

\section{Acknowledgements}

This work has been carried out through a Mobility Fellowship for Senior Researchers and Professors Program, granted by the Education Ministry (Spanish Government). PLS participates with partial funding from the Natural Environment Research Council. We acknowledge the Ministerio de Medio Ambiente, Medio Rural y Marino (MARM) for providing their groundwater chemistry data for boreholes in the Duero Basin. We also acknowledge laboratory staff from IGME and BGS for carrying out chemical analysis of groundwater samples, and from the University of Valladolid for analysis of arsenic species. EGF acknowledges the help of a number of IGME and external colleagues during the course of the conduct of this research. Coworkers from Salamanca Unit of IGME provided useful geological, mineralogical and tectonic information. Finally, sincere thanks go to to José Luis Simón from the University of Zaragoza for advice on tectonic structures, and Javier Sánchez San Román, from the University of Salamanca, for advice on the hydrogeology of the area. 
Giménez-Forcada, E.; Smedley, P.L. (2014). Geological factors controlling occurrence and distribution of arsenic in groundwaters from the southern margin of the Duero Basin, Spain. Environ Geochem Health. 36(6):1029-47.

DOI: 10.1007/s10653-014-9599-2

\section{References}

Alonso Gavilán, G., (coord.), Armenteros, I., (coord.), Carballeira, J., Corrochano, A., Huerta, P. y Rodríguez, J.M. 2004. Cuenca del Duero. In: Geología de España, Ed. J.A. Vera. SGEIGME, Madrid, 550-556.

Appelo, C.A.J., Postma, D., 2009. Geochemistry, groundwater pollution. A.A. Balkema Publishers. 2nd edition. 649 p.

Appleyard, S.J., Angeloni, J., Watkins, R., 2006. Arsenic-rich groundwater in an urban area experiencing drought increasing population density, Perth, Australia. Applied geochemistry, 21, 83-97.

Aragonés, N. Pérez-Gómez, B., Pollán, M., Ramis, R., Vidal, E., Lope, V., García-Pérez, J., Boldo, E. and López-Abente, G. 2009. The striking geographical pattern of gastric cancer mortality in Spain: environmental hypotheses revisited. BMC Cancer, 9, 316.

Ares Yañez, M; Gutiérrez Alonso, G.; Díez Balda, M.A.; Álvarez, F., 1995. La prolongación del Despegue de Salamanca (segunda fase de deformación varisca) en el Horst de Mirueña (Zona Centro Ibérica). Rev. Soc. Geol. España 8, 175-191.

Armenteros, I., Corrochano, A., Alonso Gavilán, G., Carballeira, J., Rodríguez, J. M. (2002): Duero basin (northern Spain). In: The Geology of Spain (W. Gibbons \&T. Moreno, eds.). Geological Society, London, 304-315.

Barrios Sánchez, S.; Reguilón Bragado, R.; Gonzalo Sanz, I. 2008. Caracterización Mineralógica de los Filones de Cuarzo con $\mathrm{S}^{=}$en la Mina Santa Cruz. Provincia de Ávila (España). Macla 9, 45-46.

Barroso, J.L., Lillo, J., Sahún, B., Tenajas, J., 2002. Caracterización del contenido de arsénico en las aguas subterráneas de la zona comprendida entre el río Duero, el río Cega y el Sistema Central. Presente y Futuro del agua subterránea en España y la Directiva Marco Europea, Zaragoza, 77-84.

BOE 45, 21 febrero 2003. REAL DECRETO 140/2003, de 7 de febrero, por el que se establecen los criterios sanitarios de la calidad del agua de consumo humano. http://www.boe.es/boe/dias/2003/02/21/pdfs/A07228-07245.pdf

Brookins, D.G. (1988) Eh-pH diagrams for geochemistry, Springer-Verlag New York, 176p.

Busbee, M.W., Kocar, B.D., Benner, S.G., 2009. Irrigation produces elevated arsenic in the underlying groundwater of a semi-arid basin in Southwestern Idaho. Applied Geochemistry 24, 843-859.

CHD, Confederación Hidrográfica del Duero, 1998. Plan hidrológico de la cuenca del Duero. Ministerio de Obras Públicas, Transportes y Medio Ambiente. Dirección General de Obras Hidráulicas. In: www.chduero.es

CHD, Confederación Hidrográfica del Duero, 2006. Confederación Hidrográfica del Duero. Memoria 2004-2005. Edita: Confederación Hidrográfica del Duero. In: www.chduero.es 
Giménez-Forcada, E.; Smedley, P.L. (2014). Geological factors controlling occurrence and distribution of arsenic in groundwaters from the southern margin of the Duero Basin, Spain. Environ Geochem Health. 36(6):1029-47.

DOI: 10.1007/s10653-014-9599-2

Chowdhury, T.R., Basu, G.K., Mal, B.K., Biswas, B.K., Samanta, G., Chowdhury ,U.K., Cha C. R., Lodh D., Roy S.R., Saha K. C., Roy S., Kabir S., Quamruzzaman Q., Chakraborti D., 1999 Arsenic poisoning of Bangladesh groundwater. Nature 401, 545-546.

Colmenero, J. R., Rodríguez, J. M., Gómez, J. J. y Carrasco, P., 2001. Estratigrafía del subsuelo y evolución sedimentaria del sector sur de la cuenca terciaria del Duero. Geotemas, 3, 129-132.

Day, J.A.; Montes-Bayon, M. Vounderheide, J.A. Caruso, J.A.2002. A study of method robustness for arsenic speciation in drinking water samples by anion exchange HPLC-ICPMS. Anal. Bioanal. Chem. 373: 664-668.

De Vicente, G. Vegas, R., Muñoz Martín, A., Silva, P.G., Andriessen, P., Cloetingh, S., González Casado, J.M., Van Wees, J.D., Álvarez, J., Carbó, A. and Olaiz, A., 2007. Cenozoic thickskinned deformation and topography evolution of the Spanish Central System. Global \& Planetary Change, 58, 335-381.

Delgado, J., Medina, J., Vega, M., Carretero, C., Pardo, R., 2009. Los Minerales de la Arcilla y el Arsénico en los Acuíferos de la Tierra de Pinares. Macla 11, 75-76.

Di Benedetto, F., Costagliola, P., Benvenuti, M., Lattanzi, P., Romanelli, M., Tanelli, G.,

2006. Arsenic incorporation in natural calcite lattice: evidence from electron spin echo spectroscopy. Earth Planet. Sci. Lett. 246, 458-465.

Dove, PM., Rimstidt, J.D., 1985 The solubility and stability of scorodite, $\mathrm{FeAsO}_{4} \cdot 2 \mathrm{H}_{2} \mathrm{O}$. American Mineralogist, 70, 838-844.

Drobner, E., Huber, H., Stetter, K.O., 1990. Thiobacillas ferrooxidans, a facultative hydrogen oxidizer. Appl Environ Microbiol 56, 2922-2923.

Fernández, L., Vega, M, Carretero, M., Pardo, R, Debán, L. y Barrio, V., 2004. Hidrogeología de los acuíferos de la zona Vallelado-Mata de Cuéllar, Segovia afectados por altos contenidos de arsénico. Abstract VIII Simp. Hidrogeol., Zaragoza, 45-50.

Fujii, R., Swain, W.C., 1995. Areal distribution of trace elements, salinity, major ions in shallow ground water, Tulare basin, Southern San Joaquin Valley, California. U.S. Geol. Surv. Wat. Res. Inv. Rep. 95-4048, 67 p.

García-Sanchez, A., Alvarez-Ayuso, E., 2003. Arsenic in soils waters its relation to geology mining activities, Salamanca Province, Spain. Journal of Geochemical Exploration 80, 6979.

García-Sánchez, A., Moyano, A., Mayorga, P., 2005. High arsenic in groundwater of central Spain. Env.Geol. 47, 847-854.

Giménez-Forcada E., 2010. Dynamic of Sea Water Interface using Hydrochemical Facies Evolution Diagram. Groundwater 48, 212-216.

Giménez-Forcada et al., 2010a. Analysis of spatial variability of arsenic concentration in spring waters using principal components analysis geostatistical tools. Application to 
Giménez-Forcada, E.; Smedley, P.L. (2014). Geological factors controlling occurrence and distribution of arsenic in groundwaters from the southern margin of the Duero Basin, Spain. Environ Geochem Health. 36(6):1029-47.

DOI: 10.1007/s10653-014-9599-2

Central Iberian Zone, Province of Ávila, Spain. Arsenic in The Environment. J. Bundschuh \& P. Bhattacharya, eds. Balkema Publishers, 33-35.

Giménez-Forcada et al., 2010b. Hydrogeotoxicity by as in spring waters from Sierra de Gredos - Duero basin area, Spain. WRI-13 Proceedings Water-Rock Interaction. Balkema Publishers, 453-456.

Gómez, J.J., Lillo, F.J., Sahún, B., 2006. Naturally occurring arsenic in groundwater identification of the geochemical sources in the Duero Cenozoic Basin, Spain. Environ Geol 50, 1151-1170.

Gómez Ortiz, D., Babín Vich, R., 1996. La tectónica alpina en el sector centro-oriental del borde norte del Sistema Central, Provincia de Segovia, España. Geogaceta 19, 19-22.

Hering, J.G., Kneebone, P.E., 2001. Biogeochemical Controls on Arsenic Occurrence Mobility in Water Supplies. In: W.T. Frankenberger, Editor, Environmental Chemistry of Arsenic. Marcel Dekker, New York, 155-181.

Herrero Matías, 1999. El papel explicativo de las rocas filonianas en la evolución morfoestructural de áreas de zócalo cristalino: La Sierra de Ávila. Cuaternario y Geomorfología, 13 51-60.

ITGE, 1995. Informe de los estudios y obras realizados para el abastecimiento de agua potable en varios municipios de la provincia de Ávila durante los años 1994 y 1995. Tomo I-II. Convenio con la Excma. Diputación Provincial de Ávila.

Jiménez Benayas et al., 1997. Mapa Geológico y Minero de Castilla y León. Escala 1:400.000. Junta de Castilla y León-SIEMCALSA. 457 pp.

Komorowicz, I. Barałkiewicz, D. 2011. Arsenic and its speciation in water samples by high performance liquid chromatography inductively coupled plasma mass spectrometry-Last decade review. Talanta, 84, 247-261.

Li,Y., Low, G.K.-C., Scott, J.A., Amal, R. 2010. Arsenic speciation in municipal landfill leachat. Chemosphere 79, 794-801.

Lopez-Abente, G., Aragonés, N., Ramis, R., Hernandez-Barrera, V., Perez-Gomez, B., EscolarPujolar, A. and Pollan, M. 2006. Municipal distribution of bladder cancer mortality in Spain: possible role of mining and industry. BMC Public Health, 6: 17.

Lowers, H.A., Breit, G.N., Foster, A.L., Whitney, J., Yount, J., Uddin, M. N., Muneem, A.A., 2007. Arsenic incorporation into authigenic pyrite, Bengal Basin sediment, Bangladesh. Geochimica et Cosmochimica Acta 71, 2699-2717.

Marchán-Sanz, C. (coord.), 2010. Atlas del medio natural y de los recursos hídricos de la provincia de Ávila. Instituto Geológico y Minero de España - Diputación de Ávila. Madrid. $240 \mathrm{pp}$.

Masuda, H., Mitamura, M., Farooqi, A.M., Muhanmad, N., Owada, M., Okazaki, K. Seddique, A.A., 2010 Geologic structure geochemical characteristics of sediments of fluoride arsenic 
Giménez-Forcada, E.; Smedley, P.L. (2014). Geological factors controlling occurrence and distribution of arsenic in groundwaters from the southern margin of the Duero Basin, Spain. Environ Geochem Health. 36(6):1029-47.

DOI: 10.1007/s10653-014-9599-2

contaminated groundwater aquifer in Kalalanwala its vicinity, Punjab, Pakistan. Geochem. J. 44, 489-505.

Milstein, L.S., Essader, A. Pellizzari, E.D., Fernando, R.A. Akinbo, O. 2002. Selection of a suitable mobile phase for the speciation of four arsenic compounds in drinking water samples using ion-exchange chromatography coupled to inductively coupled plasma mass spectrometry. Environ. Int. 28, 277-283.

MIMAM, 2005. Informe Resumen de las artículos 5 y 6 de la Directiva Marco del Agua. Demarcación Hidrográfica del Duero. Cap. 2. Caracterización de la demarcación Hidrográfica. 7.1 Version 7.1, Ministerio de Medio Ambiente, March 2005, 113 p.

Moyano, A., García-Sánchez, A., Mayorga, P., Anawar, H.M., Alvarez-Ayuso, E., 2008. Impact of irrigation with arsenic-rich groundwater on soils crops. Journal of Environmental Monitoring 11, 498-502.

Mukherjee, A., Fryar, A.E., Howell, P.D., 2007. Regional hydrostratigraphy groundwater flow modelling in the arsenic affected areas of the western Bengal Basin, West Bengal, India. Hydrogeology Journal 15, 7, 1397-1418.

Mukherjee, A., Fryar, A.E., Scanlona, B.R., PBhattacharya, P., Bhattacharya, A., 2011. Elevated arsenic in deeper groundwater of the western Bengal basin, India: extent controls from regional to local scale. Applied Geochemistry 26, 600-613.

Murciego, A. Pellitero Pascual, E. Rodríguez, M.A., Álvarez-Ayuso, E. García-Sánchez, A. Rubio, F., Juan Rubio, J., 2009. Arsenopyrite weathering products in Barruecopardo mine tailings, Salamanca, Spain. Macla 11, 133-134.

Nakaya, S., Natsume, H., Masuda, H., Mitamura, M., Biswas, D. K. Seddique, A. A., 2011 Effect of groundwater flow on forming arsenic contaminated groundwater in Sonargaon, Bangladesh. J. Hydrol. 409, 724-736.

Nath, B., Chakraborty, S., Burnol, A., Stüben, D., Chatterjee, D. Charlet, L., 2009 Mobility of arsenic in the subsurface environment: An integrated hydrogeochemical study sorption model of the sandy aquifer materials. J. Hydrol. 364, 236-248.

Palencia Ortas A., Osete M.L., Vegas R., Silva P., 2006. Paleomagnetic study of the Messejana Plasencia dyke, Portugal Spain: A lower Jurassic paleopole for the Iberian plate. Tectonophysics 419, 455-472.

Pardo, R., Vega, M., Carretero, M., Medina, J., Delgado, J. 2008. The occurrence geochemistry of arsenic in an aquifer of the Tierra de Pinares region, Duero basin, Spain. Abstract 20 Int. Congress Arsenic in the environment. Valencia.

RD 140/2003, de 7 de febrero, por el que se establecen los criterios sanitarios de la calidad del agua de consumo humano. BOE 21.02.03.

Rickard, D., 1997 Kinetics of pyrite formation by the H2S oxidation of Fe(II) monosulfide in aqueous solutions between 25125 C: The rate equation. Geochim. Cosmochim. Acta 61, 115-134. 
Giménez-Forcada, E.; Smedley, P.L. (2014). Geological factors controlling occurrence and distribution of arsenic in groundwaters from the southern margin of the Duero Basin, Spain. Environ Geochem Health. 36(6):1029-47.

DOI: 10.1007/s10653-014-9599-2

Rivett, M.O., Buss, S.R., Morgan, P., Smith, J.W.N., Bemment, C.D., 2008. Nitrate attenuation in groundwater: A review of biogeochemical controlling processes. Water Research 42, $4215-4232$.

Robertson, W.D., Russell, B.M., Cherry, J.A., 1996. Attenuation of nitrate in aquitard sediments of southern Ontario. J. Hydrol. 180, 267-281.

Robins, R.G., 1987 Solubility stability of scorodite, $\mathrm{FeAsO}_{4} \cdot 2 \mathrm{H}_{2} \mathrm{O}$ : Discussion. American Mineralogist 72, 842-844.

Sahún, B., Niñerola, S., Gómez, J. J., Lillo, J., del Olmo, P., Hernández, A., 2003. Estudio del contenido de arsénico en la zona central de la Depresión del Duero, Dirección General de Obras Hidráulicas y Calidad de las Aguas. Biblioteca del Ministerio de Medio Ambiente, $192 \mathrm{p}$.

Sahún, B.; Gómez, J.J.; Lillo, J.; Del Olmo, P., 2004. Arsénico en aguas subterráneas e interacción agua-roca: Un ejemplo en la cuenca terciaria del Duero, Castilla y León, España. Rev. Soc. Geol. España 17, 137-155.

Sánchez, F.J., 2006. Los grandes acuíferos de la Cuenca del Duero. In: http://www.unizar.es/fnca/duero/docu/p105.pdf

Saunders, J.A., Lee, M.K., Uddin, A., Mohammed, S., Wilkin, R.T., Fayek, M., Korte, N. E., 2005. Natural arsenic contamination of Holocene alluvial aquifers by linked tectonic, weathering, microbial processes. G3: Geochemistry, Geophysics, Geosystems 6, 1-7.

Schreiber, M.E., Gotkowitz, M.B., Simo, J.A., Freiberg, P.G., 2003. Mechanisms of Arsenic. Release to Groundwater from Naturally Occurring Sources, Eastern Wisconsin. In: Welch, A. K. Stollenwerk, eds. Arsenic in Groundwater. Boston: Kluwer Academic Publishers, 488 p.

Seddique, A. A., Masuda, H., Mitamura, M., Shinoda, K.,Yamanaka, T., Itai, T., Maruoka, T., Uesugi, K., Ahmed, K.M. Dipak, K. B., 2008 Biotite releasing arsenic into Holocene groundwater aquifer in Bangladesh. Appl.Geochem. 23, 2236-2248.

Simón Gómez, J.L., 1996. Estudio estructural de la Comarca de La Moraña. Dept. Geología. University of Zaragoza. 41 p. Unpublished.

Smedley, P.L. and Kinninburgh, D.G., 2002. A review of the source, behaviour distribution of arsenic in natural waters. Applied Geochemistry 17, 517-568.

Smedley, P.L., Edmunds, W.M., 2002. Redox patterns and trace-element behaviour in the East Midlands Triassic Sandstone Aquifer, U.K. Ground Water 40, 44-58.

Smedley, P L, Nicolli H B, Macdonald D M J, Barros A J and Tullio J O 2002. Hydrogeochemistry of arsenic and other inorganic constituents in groundwaters from La Pampa, Argentina. Applied Geochemistry, 17, 259-284.

Smedley, P.L., Knudsen, K., Maiga, D., 2007. Arsenic in groundwater from mineralised Proterozoic basement rocks of Burkina Faso. Applied Geochemistry 22, 1074-1092. 
Giménez-Forcada, E.; Smedley, P.L. (2014). Geological factors controlling occurrence and distribution of arsenic in groundwaters from the southern margin of the Duero Basin, Spain. Environ Geochem Health. 36(6):1029-47.

DOI: 10.1007/s10653-014-9599-2

Ubanell, A.G., 1985. Características principales de la fracturación tardihercínica en un segmento del Sistema Central Español. Cuad. Geo. Ibe. 7, 591-605.

Varela, M., Dimas, M., Villaverde, J., Borrell, E. 2002. Cartografía de vulnerabilidad de acuíferos subterráneos a la contaminación en la Cuenca Hidrográfica del Duero. Dirección General de Obras Hidráulicas y Calidad de las Aguas - Centro de Estudios Hidrográficos, CEDEX. 181 p.

Vilanova, E., Mas-Pla, J., Menció, A., 2008. Determinación de sistemas de flujo regionales y locales en las depresiones tectónicas del Baix Empordà y La Selva (NE de España) en base a datos hidroquímicos e isotópicos. Boletín Geológico y Minero, 119 (1): 51-62

Welch, A. H., Lico, M.S., 1998. Factors controlling As $U$ in shallow ground water, southern Carson Desert, Nevada. Applied Geochemistry 13, 521-539.

Welch, A.H, Westjohn, D.B., Helsel, D.R., Wanty, R.B., 2000. Arsenic in ground water of the United States: occurrence geochemistry. Ground Water 38, 589-604.

WHO Guidelines for drinking-water quality, fourth edition World Health Organization 2011 http://whqlibdoc.who.int/publications/2011/9789241548151 eng.pdf 